(C) 2022, The Authors. Published by Elsevier Inc. and Fass Inc. on behalf of the American Dairy Science Association ${ }^{\circledR}$. This is an open access article under the CC BY license (http://creativecommons.org/licenses/by/4.0/).

\title{
Secretory immunoglobulin A from human milk hydrolyzes 5 histones and myelin basic protein
}

\author{
Ivan Yu. Kompaneets, ${ }^{1} \odot$ Sergey E. Sedykh, ${ }^{1} \odot$ Valentina N. Buneva, ${ }^{1} \odot$ Pavel S. Dmitrenok, ${ }^{2} \odot$ \\ and Georgy A. Nevinsky ${ }^{1 *}$ (1) \\ ${ }^{1}$ Institute of Chemical Biology and Fundamental Medicine of Siberian Branch of Russian Academy of Sciences, 8 Lavrentiev Ave., \\ Novosibirsk 630,090, Russia \\ ${ }^{2}$ G. B. Elyakov Pacific Institute of Bioorganic Chemistry, Far East Division, Russian Academy of Sciences, Vladivostok 690,022, Russia
}

\begin{abstract}
Mother's milk provides newborns with various nutrients (e.g., enzymes, proteins, peptides, hormones, antibodies) that help babies grow and protect them from bacterial and viral infections. The functions of many components of breast milk can be very different from their corresponding functions in body fluids of healthy adults. Catalytic antibodies (abzymes) that hydrolyze peptides, proteins, DNA, RNA, and oligosaccharides were detected not only in human milk, but also in the blood sera of autoimmune patients. However, abzymes with unexpected synthetic activities (lipids, oligosaccharides, and protein kinase activities) were revealed in milk that were not found in the blood of autoimmune patients. The nutrition of infants with fresh milk has a very specific role; newborns are well protected by antibodies of mother's milk (passive immunity). Protease abzymes were found in the blood sera of autoimmune patients, whereas healthy humans usually do not contain such autoantibodies. Here, we present the first evidence that the milk of healthy mothers contains secretory (s) IgA that effectively hydrolyze 5 histones (e.g., $\mathrm{H} 1, \mathrm{H} 2 \mathrm{~A}, \mathrm{H} 2 \mathrm{~B}, \mathrm{H} 3$, and $\mathrm{H} 4$ ) and myelin basic protein (MBP). Several rigid criteria were applied to show that protease activity is an intrinsic property of sIgA. Milk abzymes against 5 histones cannot hydrolyze different control proteins except histones and MBP, whereas autoantibodies against MBP split this protein and 5 histones. Antibodies against histones and MBP exhibit complexation polyreactivity as well as specific and unusual catalytic cross-reactivity. With some exceptions, the specific sites of hydrolysis of $\mathrm{H} 1, \mathrm{H} 2 \mathrm{~A}$, and $\mathrm{H} 2 \mathrm{~B}$ by sIgA against histones do not coincide with the sites of hydrolysis by abzymes against MBP. On the whole, fresh human milk is a very specific source of many of the most unusual antibodies and abzymes.
\end{abstract}

Received June 24, 2021.

Accepted October 10, 2021

*Corresponding author: nevinsky@niboch.nsc.ru
Key words: human milk, abzyme, hydrolysis, histone, myelin basic protein

\section{INTRODUCTION}

Antibodies (Abs) against stable analogs of transition states and natural autoantibodies with catalytic activities are known as "abzymes," and they are well described in the literature (Nevinsky and Buneva, 2003, 2005; Keinan, 2005; Nevinsky, 2010, 2011a, 2016, 2017). The spontaneous and antigen-stimulated development of autoimmune pathologies (AIP) leads to the production of autoantibodies-abzymes (ABZ) against lipids, polysaccharides, peptides, proteins, DNA, and RNA and their complexes (Nevinsky and Buneva, 2003, 2005; Keinan, 2005; Nevinsky, 2010, 2011a, 2016, 2017). In the blood sera of AIP patients, different ABZ were found directly against antigens with conformation, mimicking transition states of chemical reactions. In addition, secondary anti-idiotypic ABZ to active sites of various enzymes were also revealed, which may be explained by Jerne's anti-idiotypic network model (Jerne, 1974). The existence of ABZ in blood sera is a very clear sign of the occurrence of autoimmune processes in the mammalians (Nevinsky and Buneva, 2003, 2005; Nevinsky, 2010, 2011a, 2016, 2017; Keinan, 2005). To date, IgG or IgM, and IgA hydrolyzing, DNA, RNA (Shuster et al., 1992; Baranovsky et al., 1997; Baranovskii et al., 1998; Andrievskaya et al., 2000, 2002), oligosaccharides (Savel'ev et al., 1999, 2001; Neustoev et al., 2003), oligopeptides, and proteins (Paul et al., 1989; Li et al., 1995; Kalaga et al.,1995; Lacroix-Desmazes et al., 1999; Thiagarajan et al., 2000; Polosukhina et al., 2004, 2006; Baranova et al., 2009) were found in the blood of patients with various AIP and some viral diseases (Nevinsky and Buneva, 2003, 2005; Keinan, 2005; Nevinsky, 2010, 2011a, 2016, 2017). Because of the absence of manifested immunization, the existence of any abzymes in mammals without any immune diseases was considered not possible. For example, ABZ were not found in healthy people and patients with 
pneumonia, influenza, tuberculosis, tonsillitis, duodenal ulcer, and some oncological diseases (cancer of the breast, intestines, and uterus), demonstrating no very severe infringements of the immune status (Keinan, 2005; Nevinsky and Buneva, 2003, 2005; Nevinsky, 2010, 2011a, 2016, 2017).

A special group of healthy humans is pregnant and lactating women. Breast milk contains IgA, secretory (s) $\operatorname{Ig} \mathrm{A}$, IgG, and $\operatorname{IgM}$, of which $\operatorname{sIgA}$ is the major component (>85-90\%; Mestecky et al., 1986; Hanson et al., 1994). Today, the origin of milk IgG antibodies is still debated; they may be partially produced locally by the mother's mammary gland-specific cells as well as partially moved from the circulation system of the mother's blood (Mestecky et al., 1986). Immunoglobulin A antibodies are synthesized by the local immune system of the mammary gland B-lymphocytes (Hanson et al., 1994). Secretory IgA is assembled when dimeric IgA produced by plasma cells in the mammary stroma bind to the first domain of the polymeric immunoglobulin receptor on the basolateral surface of the epithelium (Bakos et al., 1991). The complex is internalized, the cytoplasmic part of the receptor cleaves, and the remaining protein is transported into milk. During lactation, antigen-stimulated B cells in Peyer's patches switch from IgM production to dimeric IgA and migrate to the mammary gland (Roux et al., 1977; Weisz-Carrington et al., 1978).

The immune system of newborns during the first 5 to 6 mo of life is immature; the respiratory and gastroenterological tract mucous surfaces of newborns are still poorly filled with their antibodies (Hanson et al., 1979). Infants begin to produce IgA antibodies in the intestine in the first 3 mo of life. However, newborns are well protected by Abs of mother's milk (passive immunity), which coats the mucous membranes with antibodies against bacterial, viral, and other components (Hanson et al., 1979). Breast milk sIgA remains high and active during at least 7 to 8 mo after birth and play an important role in maintaining the passive humoral response (Rechtman et al., 2002).

Interestingly, during pregnancy and after the beginning of the lactation, women show a sharp exacerbation of autoimmune reactions similar to those in typical autoimmune diseases, including systemic lupus erythematosus (SLE), multiple sclerosis, anti-phospholipid syndrome, thyroiditis, and renal insufficiency (Amino et al., 1982; Freeman et al., 1986; Hazes, 1991; Dayan and Daniels, 1996; Tanaka et al., 2000). Pregnancy causes a range of physiological changes in the immune system and kidneys, leading to an increased risk of disease exacerbation and adverse maternal and fetal outcomes such as preeclampsia, fetal loss, and preterm birth (Petri, 1994; Kattah and Garovic, 2015). Systemic lupus erythematosus is a common disease during pregnancy (Eudy et al., 2018; Baalbaki et al., 2020) and often leads to situations where it is binomially harmful to the mother and fetus (Rodrigues et al., 2020). Several studies confirm that disease activity and the incidence of SLE exacerbate during pregnancy and within 3 mo after delivery (Eudy et al., 2018; Tincani et al., 2019; Baalbaki et al., 2020). For many years, pregnancy has been considered contraindicated in patients with SLE, especially with kidney damage (Moroni and Ponticelli, 2016).

Multiple sclerosis sometimes goes into remission in the third trimester of pregnancy but worsens in the first postpartum period (Alroughani et al., 2018). Thyroid autoimmune reactions refer to the presence of antibodies to thyroid peroxidase or thyroglobulin, antibodies to thyroid-stimulating hormone receptors, or a combination of both, and these antibodies are present in about $18 \%$ of pregnant women (De Leo and Pearce, 2018). Postpartum thyroiditis is significantly more common in women with thyroid antibodies during pregnancy than in women without thyroid antibodies.

Thus, many different AIP can be "activated" or "triggered" in healthy women during their pregnancy and after childbirth (Amino et al., 1982; Freeman et al., 1986; Hazes, 1991; Dayan and Daniels, 1996; Buneva et al., 1998, 2003; Tanaka et al., 2000; Savel'ev et al., 2001; Semenov et al., 2004). The periods of pregnancy and the beginning of the lactation, as shown earlier (Buneva et al., 1998, 2003; Nevinsky and Buneva, 2003, 2005; Nevinsky, 2010, 2011a, 2016, 2017), are special periods when the immune system of women produces not only various autoantibodies without but also with catalytic activity. The appearance of abzymes in the blood and milk indicates the development of autoimmune reactions in women's organs.

It was suggested earlier that various AIP can be originated from defects of hematopoietic stem cells (Watanabe-Fukunada et al., 1992). As shown earlier (Andryushkova et al., 2006, 2007; Doronin et al., 2016; Aulova et al., 2018), the development of various autoimmune diseases occurs as a result of specific changes in the differentiation profiles of bone marrow stem cells.

Spontaneous and antigen-accelerated development of SLE in MRL-lpr/lpr mice (Andryushkova et al., 2006, 2007) and multiple sclerosis in EAE C57BL/6 mice (Doronin et al., 2016; Aulova et al., 2018) results in the specific and very similar reorganizations of immune systems of these mice, which is associated with a production of ABZ that hydrolyzes DNA and proteins. During 4 to $14 \mathrm{~d}$ after delivery, the onset of lactation occurs and specific changes occur in the differentiation profiles of bone marrow stem cells, which are close in lactation to those in mice with SLE at the stage of profound 
pathology (Andryushkova et al., 2006, 2007). These changes in the differentiation profiles in lactating mice, as in mice with deep SLE pathology, lead to the production of autoantibodies with high catalytic activity. However, changes in the differentiation profile in lactating mice are usually temporary and return to normal after 1 to 2 mo, whereas in mice with SLE, they deepen further with the development of the disease (Andryushkova et al., 2006, 2007). From our point of view, the peculiarity of the reorganization of the immune system of a pregnant woman is the "switching-on" of a special "immune-memory," which accumulates all information about harmful environmental factors during pregnancy (for a review, see Andryushkova et al., 2006, 2007). The immunization of pregnant cows with different antigens at 1 to 3 mo (but not more) before the appearance of the newborn results in the appearance in milk Abs in high concentrations (Fey et al., 1973). Immunization of pregnant mice with DNA also leads to a sharp increase in the concentration of antibodies and abzymes in the blood of these animals after the onset of lactation (Buneva et al., 1998, 2003; Andryushkova et al., 2007). Moreover, different antigens of food, bacteria, or viruses can enter into mammals orally as well as by injection to the blood. An increase in the titer of abzymes in the blood and milk of women before and especially after childbirth can only be part of the overall process of restructuring the immune system of women and, as a result, the production of auto-Abs and abzymes triggered by specific immune memory (Buneva et al., 1998, 2003; Savel'ev et al., 2001; Semenov et al., 2004).

Histones and their different posttranslational forms bear a vital role in the functioning and remodeling of chromatin, including the transcription of genes. In addition, free extracellular histones act as damage molecules, causing systemic toxic effects through inflammatory pathways and activation of toll-like receptors (Chen et al., 2014). An elevated level in blood sera of nucleosome fragments, free histones, and their complexes with DNA is associated with several pathophysiological processes, including progression of several autoimmune and inflammatory diseases and cancer (Chen et al., 2014).

Myelin basic protein (MBP) is the main component of the myelin-proteolipid sheath of axons. Abzymes that hydrolyze MBP and 5 histones were found in the blood of patients with HIV (Polosukhina et al., 2004, 2006; Baranova et al., 2016, 2017a, 2017b, 2018, 2019a, 2020, 2021), SLE (Bezuglova et al., 2011), multiple sclerosis (Parshukova et al., 2019; Baranova et al., 2019b), and in mice with experimental encephalomyelitis (Aulova et al., 2018).

Similar to blood sera of patients with AIP, small subfractions of milk polyclonal $\operatorname{IgG}$ and sIgA anti- bodies split RNA, DNA (Buneva et al., 1998; 2003), and all ribonucleotides (nucleoside mono-, di-, and triphosphates; NMP, NDP, and NTP), and possess phosphatase (Semenov et al., 2004) and amylase activities (Savel'ev et al., 2001). Human milk contains very unusual $\mathrm{ABZ}$, catalyzing not only the hydrolytic but also the synthetic reaction, including phosphorylation of more than 15 different milk proteins (Kit et al., 1996; Nevinsky et al., 1998), unique lipids (Gorbunov et al., 2000, 2005), and polysaccharides (Karataeva et al., 2006a,b), which were not found in the patients with AIP. Breast milk contains SIgA in very high concentrations, showing significantly higher enzymatic activities compared to milk IgG. Therefore, analysis of sIgA is of particular interest. We were interested to understand whether there are abzymes with MBP- and histonehydrolyzing activities in the milk of healthy women.

In this study, we analyzed, for the first time, the catalytic activity of $\operatorname{sg} \mathrm{A}$ against histones and MBP in the hydrolysis of these proteins and determined specific sites of the hydrolysis of $\mathrm{H} 1, \mathrm{H} 2 \mathrm{~A}$, and $\mathrm{H} 2 \mathrm{~B}$ histones by sIgA against these proteins using MALDI MS.

\section{MATERIALS AND METHODS}

\section{Chemicals and Donors}

Most chemicals used for this study, including a mixture of 5 histones (H1, H2A, H2B, H3, and $\mathrm{H} 4$ ), as well as homogeneous human $\mathrm{H} 1, \mathrm{H} 2 \mathrm{~A}$, and $\mathrm{H} 2 \mathrm{~B}$, were bought from Sigma-Aldrich. Protein G-Sepharose, protein A-Sepharose, and Superdex 200 HR 10/30 columns were obtained from GE Healthcare. Human MBP was bought from the Molecular Diagnostics and Therapy Center of DBRC (Russia, Moscow). Histoneand MBP-Sepharose columns were prepared according to the manufacturer's protocol using BrCN-activated Sepharose (Sigma-Aldrich), MBP, or the mixture of 5 histones.

The protocol of fresh milk sampling was confirmed by the local human ethics committee (Novosibirsk State Medical University, Novosibirsk, Russia). This ethics committee supported this study based on the guidelines of the Helsinki ethics committee. All mothers made a written agreement to donate their milk for scientific purposes. The donors reported no history of gastrointestinal, respiratory, autoimmune, rheumatologic, cardiovascular, or other system pathologies.

\section{Purification and Analysis of Antibodies}

Milk samples (100-110 mL at a time) of 7 healthy mothers (19-35 yr old) of the Russia Novosibirsk region were collected at 1 to $3 \mathrm{wk}$ after beginning lactation. 
Milk samples were collected using the standard sterile devices for the collection of excess mother's milk. Within 1 to $4 \mathrm{~h}$ after milk collection, samples were cooled to $4^{\circ} \mathrm{C}$ and then centrifuged for 25 min at 14,000 rpm at room temperature using an Eppendorf centrifuge; lipid and cells phases were removed to obtain milk plasma. Antibodies were first purified individually from each milk plasma sample according to previous studies (Kit et al., 1996; Nevinsky et al., 1998; Gorbunov et al., 2000, 2005; Karataeva et al., 2006a,b). There was no substantial variation in any analyzed parameters of Abs and abzymes (relative content of Abs and their enzymatic activities) within the sampling period of 1 to $3 \mathrm{wk}$ after onset of lactation (Kompaneets et al., 2020a,b).

The plasma samples were applied on a protein GSepharose column equilibrated with buffer A $(20 \mathrm{mM}$ Tris- $\mathrm{HCl}$ buffer, $\mathrm{pH} 7.5 ; 0.15 \mathrm{M} \mathrm{NaCl}$ ) to remove $\mathrm{IgG}$. The flow-through fractions containing sIgA were loaded on protein A-Sepharose equilibrated with buffer A. All nonspecifically adsorbed proteins and other components were eluted from protein A-Sepharose first using buffer A up to zero optical density $\left(\mathbf{A}_{280}\right)$, then using buffer containing $0.35 \mathrm{M} \mathrm{NaCl}$ and $1.0 \%$ Triton $\mathrm{X}-100$, and then again with buffer $\mathrm{A}$ to $\mathrm{A}_{280}$. The sIgA were eluted from the protein A-Sepharose specifically using $0.1 \mathrm{M}$ glycine-HCl buffer ( $\mathrm{pH}$ 2.6), neutralized immediately using $1 M$ Tris- $\mathrm{HCl}$ ( $\mathrm{pH} 9.0)$, and then dialyzed against $20 \mathrm{~m} M$ Tris- $\mathrm{HCl}$ (pH 7.5).

The sIgA preparations $(1-5 \mathrm{mg} / \mathrm{mL}, 0.3 \mathrm{~mL})$ for additional purification were incubated in $20 \mathrm{mM}$ acidic buffer (pH 2.6) containing $0.25 \mathrm{M} \mathrm{NaCl}$ at $25^{\circ} \mathrm{C}$ for 25 to $30 \mathrm{~min}$ and then subjected to fast protein liquid chromatography (FPLC) gel filtration on Superdex 200 HR 10/30, analogous to previous work (Kit et al., 1996; Nevinsky et al., 1998; Gorbunov et al., 2000, 2005; Karataeva et al., 2006a,b). All fractions collected were neutralized immediately using Tris- $\mathrm{HCl}(\mathrm{pH} 9.0)$ and dialyzed against $15 \mathrm{~m} M$ Tris- $\mathrm{HCl}$ (pH 7.5). For refolding of Abs after acidic treatment, protease activity of sIgA was determined after 1.5 to 2 wk of preparations storage in this buffer at $4^{\circ} \mathrm{C}$.

\section{Affinity Chromatography Purification of Anti-MBP slgA}

Removal of all Abs against 5 histones from total preparation of polyclonal sIgA was carried out using MBP-Sepharose bearing immobilized MBP $(5 \mathrm{~mL})$, equilibrated in buffer $\mathrm{B}(20 \mathrm{~m} M$ Tris- $\mathrm{HCl}, \mathrm{pH} 7.5)$. After Abs loading, to obtain the fraction containing sIgA against MBP, the column was washed to $\mathrm{A}_{280}$ with buffer B. Adsorbed sIgA against MBP were eluted us- ing buffer $\mathrm{B}$ containing $\mathrm{NaCl}(0.15$ and $3.0 \mathrm{M})$ and finally were specifically eluted by $0.1 \mathrm{M}$ glycine- $\mathrm{HCl}$, $\mathrm{pH}$ 2.6. The fraction eluted from MBP-Sepharose with acid buffer for additional purification from Abs against 5 histones was applied on the column of histone5-sepharose (immobilized 5 histones). The fraction of Abs eluted upon the loading and washing the column with buffer B $(5 \mathrm{~mL})$ was named anti-MBP sIgA.

The fractions eluted from MBP-Sepharose at loading and washing the column with buffer $\mathrm{B}(7 \mathrm{~mL})$ were used for purification of anti-histones sIgA using affinity chromatography on a histone-5-Sepharose column (4 $\mathrm{mL}$ ) equilibrated in buffer B. After the column washing to zero optical density $\left(\mathrm{A}_{280}\right)$ with buffer $\mathrm{B}$, adsorbed sIgA against 5 histones were eluted using buffer B, containing 0.2 and $3.0 \mathrm{M} \mathrm{NaCl}$ and then with buffer $\mathrm{pH} .2 .6$. The mixture of fractions of anti-histones $\operatorname{sIgA}$ eluted with acid buffer was run additionally through a column of MBP-Sepharose to remove possible impurities of Abs against MBP. The fraction eluted upon the loading on the column was named anti-histones sIgA.

\section{Proteolytic Activity Assay}

For analysis of protease activity, the reaction mixtures $(10-20 \mu \mathrm{L})$ contained $20 \mathrm{~m} M$ Tris- $\mathrm{HCl}$ buffer $(\mathrm{pH}$ $7.5)$, mixture of 5 histones (H1-H4) or MBP (0.7-1.0 $\mathrm{mg} / \mathrm{mL}$ ), and 0.01 to $0.2 \mathrm{mg} / \mathrm{mL}$ sIgA against MBP or 5 histones according to Baranova et al. (2016, 2017a,b, 2018, 2019a,b). These mixtures were incubated during 1 to $24 \mathrm{~h}$ at $37^{\circ} \mathrm{C}$, and the reaction was stopped by the adding of the solution containing $0.1 \%$ SDS. The efficiency of hydrolysis of MBP and 5 histones was analyzed using SDS-PAGE in 4-20\% gradient gel. The hydrolysis of proteins was visualized using Coomassie Blue or silver staining. The gels were first imaged by scanning and then quantified by Image Quant v5.2 software (Media Cybernetics, L.P.). The relative activities of sIgA were calculated from the decrease in these initial nonhydrolyzed proteins taking into account their incubation without sIgA.

\section{Application of Strict Criteria}

The application of strict criteria was done as previously described (Bezuglova et al., 2011). The sIgA were incubated in glycine- $\mathrm{HCl}$ buffer $(50 \mathrm{mM}$; pH 2.6) containing $0.25 \mathrm{M} \mathrm{NaCl}$ for $20 \mathrm{~min}$ at $25^{\circ} \mathrm{C}$. Separation of the sIgA under "acid shock" conditions was performed using FPLC gel filtration on a column of Superdex $200 \mathrm{HR}$ 10/30 equilibrated with the glycine-HCl buffer supplemented with $0.1 \mathrm{M} \mathrm{NaCl}$ as described previously (Polosukhina et al., 2004, 2006). Collected fractions were neutralized as described above. After $7 \mathrm{~d}$ of $\operatorname{sIgA}$ 
storage at $4^{\circ} \mathrm{C}$ for refolding after the acid shock, they were used in proteolytic activity assays as described above.

Electrophoretically and immunologically homogeneous IgA were mixed with Sepharose bearing immobilized polyclonal mouse IgG against the light chain of human sIgA antibodies as in Polosukhina et al. (2004, 2006). After removing the sorbent by Eppendorf centrifuge for $10 \mathrm{~min}$ at 14,000 $\mathrm{rpm}$, the supernatant became inactive in the hydrolysis of MBP and histones.

Analysis of the protein-hydrolyzing activity of sIgA after SDS-PAGE was performed similarly to the analysis of the proteolytic activity of different abzymes (Polosukhina et al., 2004, 2006; Doronin et al., 2016). The sIgA $(10-15 \mu \mathrm{g})$ were pre-incubated at $25^{\circ} \mathrm{C}$ for 25 min under nonreducing (50 $\mathrm{m} M$ Tris- $\mathrm{HCl}, \mathrm{pH} 7.5$; $1 \%$ SDS; and $10 \%$ glycerol) conditions. After standard SDS-PAGE electrophoresis to restore protease activity of sIgA, SDS was removed using incubation of the gels for $1.5 \mathrm{~h}$ at $30^{\circ} \mathrm{C}$ with $4.0 \mathrm{M}$ urea and washed 9 times (7-10 min) with $\mathrm{H}_{2} \mathrm{O}$. Then 2- to 3 -mm cross-sections of gel longitudinal slices were cut up and incubated with $60 \mu \mathrm{L}$ of $40 \mathrm{~m} M$ Tris- $\mathrm{HCl}$ buffer ( $\mathrm{pH} 7.5)$ containing $50 \mathrm{mM} \mathrm{NaCl}$ for $7 \mathrm{~d}$ at $4^{\circ} \mathrm{C}$ to allow proteins refolding and eluting from the gel. The gels were removed by centrifugation, and then the solutions were used for assay of MBP and 5 histones hydrolysis as described above. Parallel control longitudinal gel slices were used for detecting the position of sIgA on the gel by Coomassie R250 staining.

\section{MALDI-TOF Analysis of Histone Hydrolysis}

We hydrolyzed H1, H2A, or H2B using anti-MBP or anti-histones sIgA according to Baranova et al. (2016, 2017a,b, 2018, 2019a,b, 2020, 2021). The analysis of products of $\mathrm{H} 1, \mathrm{H} 2 \mathrm{~A}$, or $\mathrm{H} 2 \mathrm{~B}$ hydrolysis was carried out using the Reflex III system from Bruker company as follows: $337-\mathrm{nm}$ nitrogen laser VSL-337 ND, $3 \mathrm{~ns}$ pulse duration. Mixtures $(10 \mu \mathrm{L})$ containing $20 \mathrm{mM}$ Tris- $\mathrm{HCl}(\mathrm{pH} 7.5)$, a $0.7 \mathrm{mg} / \mathrm{mL}$ concentration of one of the histones, and $0.15 \mathrm{mg} / \mathrm{mL}$ sIgA were incubated during 0 to $24 \mathrm{~h}$. We added $1.1 \mu \mathrm{L}$ of the solutions containing $\mathrm{H} 1, \mathrm{H} 2 \mathrm{~A}$, or $\mathrm{H} 2 \mathrm{~B}$ to $1.1 \mu \mathrm{L}$ of the sinapinic acid matrix mixed with $1.1 \mu \mathrm{L}$ of $0.2 \%$ trifluoroacetic acid; 1 to $1.5 \mu \mathrm{L}$ of these mixtures were applied on the MALDI plates, which then were air-dried. Calibrations of all MALDI spectra were performed using standard protein mixtures II and I (Bruker Daltonic) in the internal or external calibration mode. The analysis of peptide molecular masses (MM), corresponding to specific sites of $\mathrm{H} 1, \mathrm{H} 2 \mathrm{~A}$, or $\mathrm{H} 2 \mathrm{~B}$ hydrolysis by different sIgA, was performed using Protein Calculator v3.3 (Scripps Research Institute).

\section{Statistical Analysis}

The mean and standard deviation of 2 or 3 independent experiments for every $\operatorname{sIgA}$ preparation are reported. Medians (M) and interquartile ranges (IQR) were estimated. The Spearman correlation coefficients between different parameters were calculated using the program OriginPro-8 (Origin Lab).

\section{RESULTS}

\section{Purification and Characterizing of slgA}

A few publications have shown that $\operatorname{IgG}$ and $\operatorname{sig} \mathrm{A}$ from sera and milk of lactating mothers possess several different catalytic activities (Buneva et al., 1998, 2003; Nevinsky and Buneva, 2003, 2005; Nevinsky, 2010, 2011a, 2016, 2017). In this study, we first analyzed the relative activities of sIgA from 7 milk samples of healthy mothers in the cleavage of MBP and 5 histones.

Electrophoretically homogeneous sIgA preparations were obtained from 7 milk samples, first by chromatography of milk proteins on protein G-Sepharose (to remove away $\operatorname{IgG}$ ), and then on protein A-Sepharose in the conditions that provided deletion of nonspecifically bound proteins. Then, sIgA were purified additionally by FPLC gel filtration in an acidic buffer to destroy immune complexes as in previous studies (Kit et al., 1996; Nevinsky et al., 1998; Gorbunov et al., 2000, 2005; Karataeva et al., 2006a,b). For analysis of an "average" situation regarding the homogeneity of sIgA, a mixture of equal amounts of sIgA from 7 human milk samples $\left(\mathbf{s I g \mathbf { A } _ { \text { mix } }}\right)$ was prepared. The $\operatorname{sIgA}\left(\mathrm{L}_{4} \mathrm{H}_{4} \mathrm{JS}\right)$ consist of 1 secretory $(\mathbf{S}), 72 \mathrm{kDa} ; 4$ heavy $(\mathbf{H}), 62 \mathrm{kDa}$; 4 light $(\mathbf{L}), 23 \mathrm{kDa}$; and 1 join $(\mathbf{J})$-chain, 23 to $24 \mathrm{kDa}$. The homogeneity of the typical $\sim 360-\mathrm{kDa}$ sIgA $\mathrm{A}_{\text {mix }}$ was confirmed using SDS-PAGE and nonreducing conditions (Figure 1a). After complete reduction of $\operatorname{sIg} \mathrm{A}_{\text {mix }}$ with dithiothreitol (DTT), only 3 bands (23, 62, and $72 \mathrm{kDa}$ ) regarding $\mathrm{L}$ and $\mathrm{H}$ chains and $\mathrm{S}$ component were revealed (Figure 1b). Because of the close-up SDS-PAGE mobility of the $\mathrm{L}$ and $\mathrm{J}$ components in the Laemmli system (Buneva et al., 1998; Nevinsky et al., 2003), they were not effectively separated. All 4 components of $\operatorname{sIg} \mathrm{A}_{\text {mix }}$ were found after electrophoresis having 2 coordinates, isoelectric point, and molecular size (data not shown).

\section{Catalytic Activity of slgA in the Hydrolysis of MBP and Histones}

First, we analyzed the hydrolysis of MBP and 5 histones with 7 individual preparations of sIgA. Figure 2a shows the data on the relative hydrolysis of 5 histones 
a)

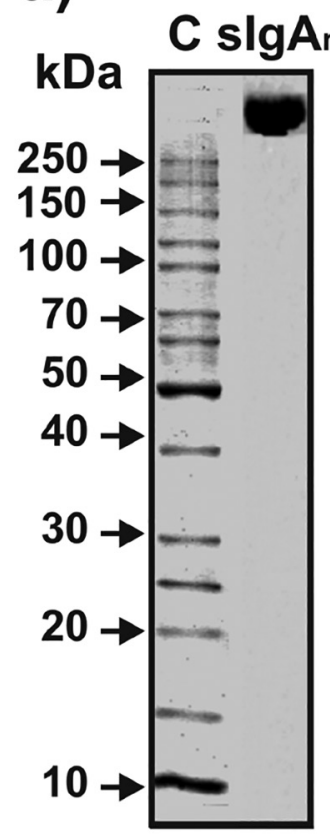

b)

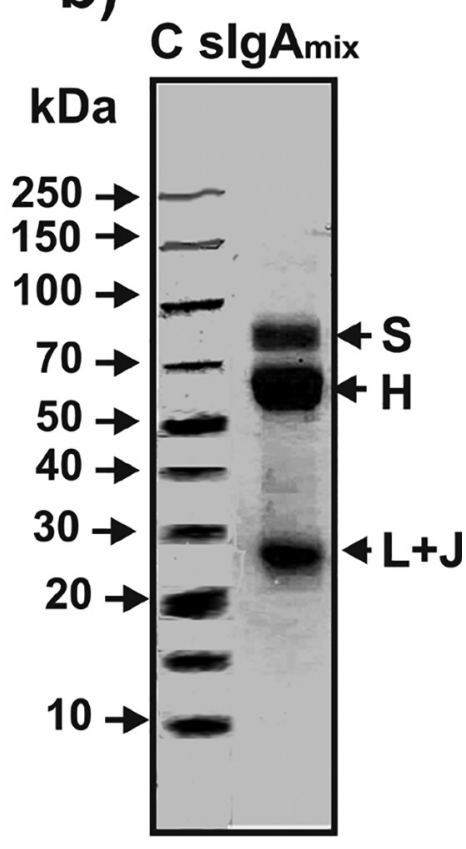

preparations could contain several related forms (18.5, 17.5 , and $\leq 14.0 \mathrm{kDa}$ ) and products of their hydrolysis (Polosukhina et al., 2004, 2006). Figure 2b demonstrates MBP hydrolysis by 7 sIgA preparations. Line $\mathrm{C}$ of Figure $2 \mathrm{~b}$ demonstrates the starting MBP preparation heterogeneity containing mainly 14.5 to 18.5 $\mathrm{kDa}$ protein forms. After $5 \mathrm{~h}$ of the incubation with 7

\section{Hydrolysis of five histones}

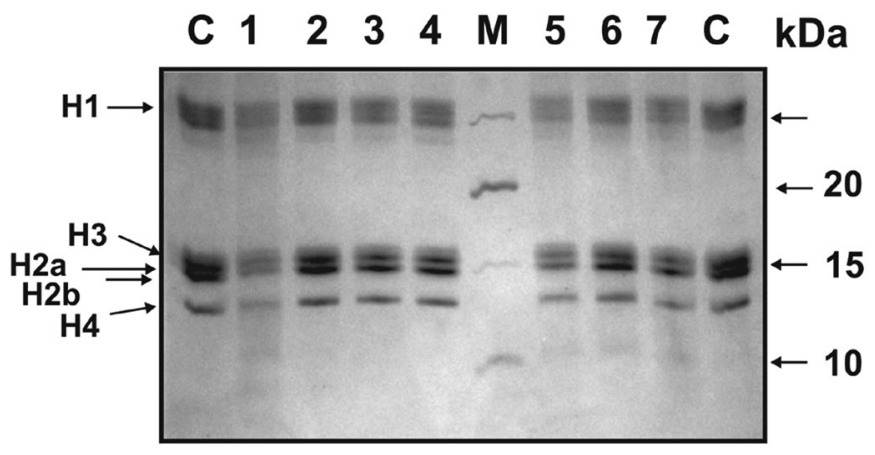

Figure 1. (a) The SDS-PAGE analysis of homogeneity of $10 \mu \mathrm{g}$ of secretory (s)IgA $A_{\text {mix }}$ corresponding to the mixture of individual sIgAs from 7 milk preparations in a nonreducing $3-18 \%$ gradient gel with the following staining by silver. (b) SDS-PAGE assay analysis of sIgA $\mathrm{A}_{\text {mix }}$ components in a reducing $12 \%$ gel with silver staining. Under the reducing conditions in the presence of dithiothreitol (DTT), the sIgA break down into their heavy $(\mathrm{H})$ and light $(\mathrm{L})$ subunits, as well as to secretory component $(\mathrm{S})$ and join chain $(\mathrm{J})$. The $\mathrm{L}$ and $\mathrm{J}$ chains have close molecular masses, and during SDS-PAGE they demonstrate close electrophoretic mobility $(\mathrm{L}+\mathrm{J})$. The arrows of lanes $\mathrm{C}$ indicate the positions of molecular mass markers ( $\mathrm{a}$ and $\mathrm{b}$ ). $\operatorname{sIg}_{\mathrm{mix}}=\mathrm{a}$ mixture of equal amounts of sIgA from 7 human milk samples.

with 7 individual sIgA preparations. The percentage of hydrolysis of 5 proteins was calculated from the loss of the intensity of 5 histone bands after their incubation with Abs in comparison to the control without sIgA. The activity of 7 sIgA in the hydrolysis of 5 histones was very different. Taking this into account, to obtain a reliable result, the incubation of the mixtures in the case of various sIgA was different from 1 to $24 \mathrm{~h}$. Then, the relative activity was recalculated for $1 \mathrm{~h}$ (Figure 2a). Taking into account the absence of a normal Gaussian distribution of the values, not only their mean values ( $15.1 \pm 20.4 \%$ for $1 \mathrm{~h}$ of incubation) but also the values of the median $(\mathrm{M}=4.9)$ and interquartile ranges (IQR $=1.4$ ) were determined. Correlation coefficients of hydrolysis by 7 sIgA preparations of 5 different histones varied in the range of 0.21 to 0.89 (average value 0.6 $\pm 0.24)$.

Electrophoretically homogeneous human MBP preparations, unfortunately, are not available. Because of cDNA alternative splicing and different partial MBP hydrolysis in the brain of various humans, these protein

\section{$\%$ of the hydrolysis $\quad 30.4 ; 16.4 ; 29.3 ; 32.6 \quad 49.9 ; 38.5 ; 34.6$ \\ $\begin{array}{lllllllll}\text { Time of the incubation } & 1 & 6 & 6 & 6 & 1 & 24 & 24 & \mathrm{~h}\end{array}$ \\ $\%$ of the hydrolysis $\quad 30.4 ; 2.7 ; 4.9 ; 5.4 \quad 49.9 ; 1.2 ; 1.4$ \\ for $1 \mathrm{~h}$}

\section{Hydrolysis of myelin basic protein}

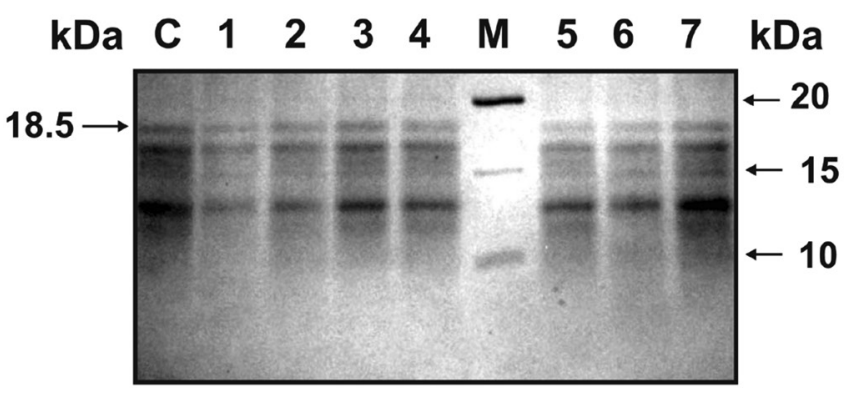

$\%$ of the hydrolysis

$30.4 ; 16.4 ; 29.3 ; 32.6$

$49.9 ; 38.5 ; 34.6$

\section{Time of the incubation $5 \mathrm{~h}$}

\section{$\%$ of the hydrolysis $\quad 6.1 ; 3.3 ; 5.9 ; 6.5 \quad 10.0 ; 7.7 ; 6.9$ for $1 \mathrm{~h}$}

Figure 2. (a) The SDS-PAGE analysis of the relative activity of 7 polyclonal secretory $(\mathrm{s}) \operatorname{IgA}(0.1 \mathrm{mg} / \mathrm{mL})$ purified by fast protein liquid chromatography (FPLC) gel filtration in the hydrolysis of 5 histones $(1 \mathrm{mg} / \mathrm{mL})$. The estimation of the relative percentage of hydrolysis was carried out on the basis of the total decrease in the amount of histones in all 5 initial bands of these proteins. (b) SDS-PAGE analysis of relative hydrolysis of myelin basic protein (MBP; $1 \mathrm{mg} / \mathrm{mL}$ ). The percentage of hydrolysis was estimated from the decrease in the 18.5 $\mathrm{kDa} \mathrm{MBP}$ band. Incubation times are shown on 2 panels. 
sIgA, all MBP forms decreased remarkably compared with the control (lane C). In contrast to hydrolysis of 5 histones, all 7 preparations of $\operatorname{sIg} \mathrm{A}$ demonstrated, to some extent, comparable relative activity in the hydrolysis of MBP (3.3-10\% during $1 \mathrm{~h}$; average value 6.6 $\pm 2.0 \% ; \mathrm{M}=6.52, \mathrm{IQR}=5.86)$. The correlation coefficient between the activity of $7 \mathrm{sIgA}$ in the hydrolysis of 5 histones and MBP is 0.61 . These data indicated that sIgA from human milk possess MBP- and histonehydrolyzing activities.

\section{Application of the Strict Criteria}

To prove that the proteolytic activity belongs to $\mathrm{sIgA}_{\text {mix }}$ and not to co-purifying canonical proteases, we used previously developed strict criteria (Paul et al., 1989; Nevinsky and Buneva, 2003, 2005; Nevinsky, 2010, 2011a, 2016, 2017). The most important criteria are as follows: (1) the electrophoretic homogeneity of ${ }_{\operatorname{sIg}} \mathrm{A}_{\text {mix }}$ (Figure 1); (2) protease activities completely disappeared from the solution after the addition of Sepharose that contained immobilized mouse IgG against $\operatorname{sIgA}$; (3) after FPLC gel filtration in an acidic buffer that destroys noncovalent complexes, the chromatographic position of the peak of sIgA and the peak corresponding to the hydrolysis of MBP and histones coincide (Figure 3a); and (4) among the known criteria, there is a very strong one: detection of enzymatic activity after SDS-PAGE. If this criterion is met, all other criteria are also always met. After SDS-PAGE, the peak of protease activity should coincide with the position of the Abs band, and there should be no other protein bands or peaks of proteolytic activity.

To exclude any contamination of Abs with hypothetical canonical proteases, sIg $\mathrm{A}_{\text {mix }}$ were subjected to SDSPAGE (Figures 3b and 3c). The MBP- and histonehydrolyzing activities were detected after extraction of proteins from the gel fragments only in the position corresponding to $\operatorname{sIg}_{\text {mix }}$ (Figure $3 \mathrm{~b}$ ). Canonical proteases have significantly fewer MM (20-40 kDa) than the intact $\operatorname{sIgA}(\sim 360 \mathrm{kDa})$. The SDS usually destroys all protein complexes. Thus, the detection of proteolytic activity in the gel fragments that corresponded only to intact $\operatorname{sIg} \mathrm{A}_{\text {mix }}$, together with the absence of any other protein bands and peaks of these activities (Figures $3 \mathrm{a}$ and $3 \mathrm{~b}$ ), provided direct evidence that $\operatorname{sIg} \mathrm{A}_{\text {mix }}$ split MBP and histones.

\section{Separation of slgA Against MBP and 5 Histones}

We tried to obtain Abs against MBP and 5 histones from initial polyclonal sIgA preparations. Because the relative content of such Abs in the total SIgA preparation is very low, to obtain antibodies against MBP and histones, we used the $\operatorname{sIg} \mathrm{A}_{\text {mix }}$ preparation and several affinity chromatographies on MBP- and histone5-Sepharose.
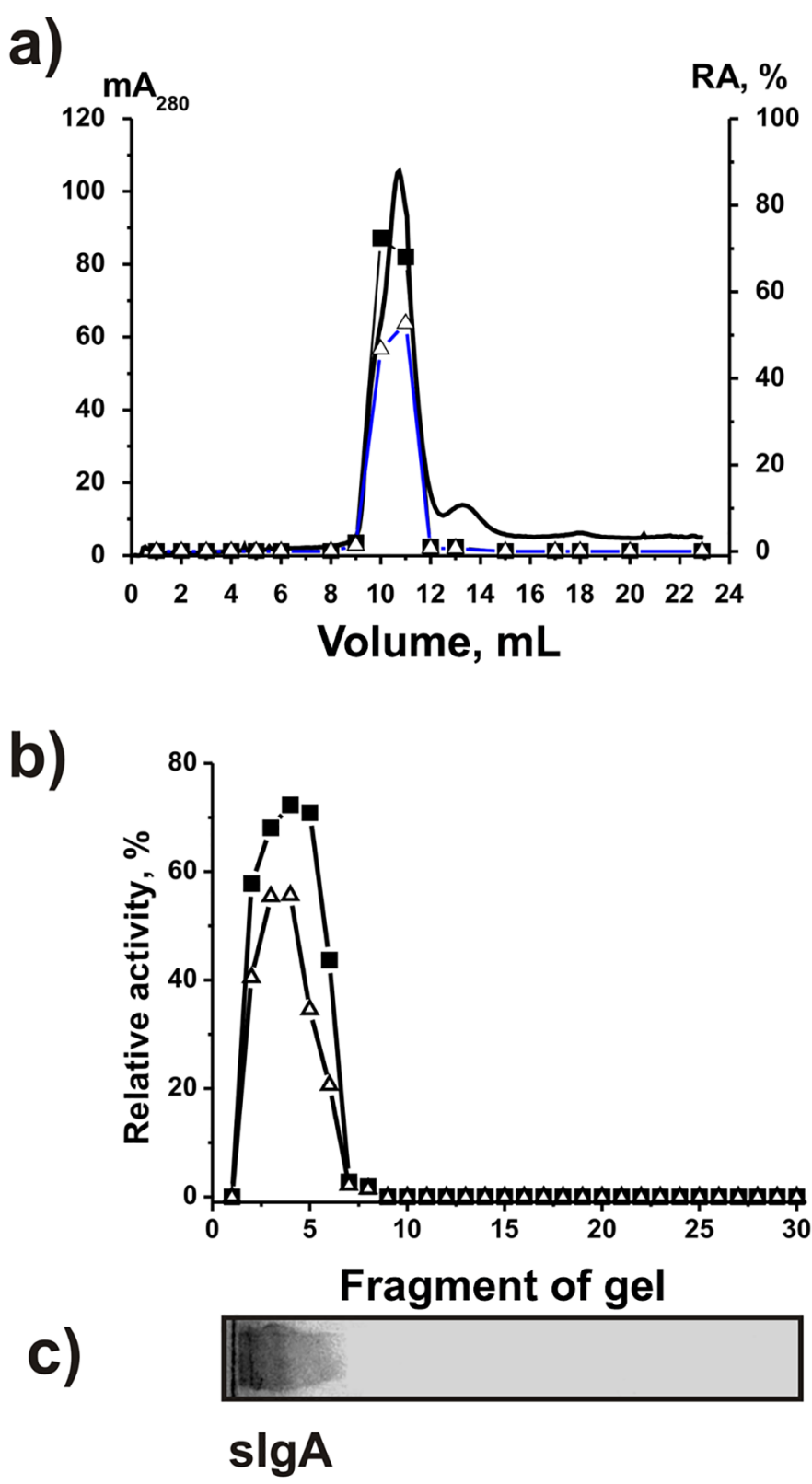

Figure 3. Verification of known strict criteria to prove that protease activity of secretory (s) $\operatorname{Ig} A_{\text {mix }}$ is own property of antibodies. (a) Analysis of sIg $\mathrm{A}_{\text {mix }}$ proteolytic activities after fast protein liquid chromatography (FPLC) gel filtration; $(-)-$ milliA $_{280}\left(\mathrm{~mA}_{280}\right)$ profile; relative activity (RA; \%) of $\operatorname{sIgA}_{\text {mix }}$ in the hydrolysis of 5 histones ( $)$ and myelin basic protein (MBP; $\Delta$ ). Complete hydrolysis of proteins for 24 $\mathrm{h}$ using $5 \mu \mathrm{L}$ of eluates was taken for $100 \%$. (b) SDS-PAGE analysis of relative activity (\%) of sIgA $\mathrm{A}_{\text {mix }}$ in the hydrolysis of 5 histones $(\mathbf{\square})$ and $\operatorname{MBP}(\Delta)$; complete hydrolysis of proteins during $24 \mathrm{~h}$ using $5 \mu \mathrm{L}$ of supernatants was taken for $100 \%$. (c) The position of $\operatorname{sIg} A_{\text {mix }}$ on the gel is shown. The error in the initial rate evaluation from 2 experiments in each case did not exceed $7-10 \%$. $\operatorname{sg} A \operatorname{mix}=$ a mixture of equal amounts of sIgA from 7 human milk samples. 
Previously, it was shown that many monoclonal antibodies are capable of forming complexes with a wide variety of foreign antigens (for review, see Zhou et al., 2007). However, the efficiency of the complexation of such antibodies with foreign antigens is usually several orders of magnitude lower than with specific antigens. Usually, nonspecific interactions with affinity sorbents against specific antigens are destroyed at 0.1 to 0.15 $M \mathrm{NaCl}$ (Nevinsky and Buneva, 2003, 2005; Nevinsky, 2010, 2011a,b, 2016, 2017). After affinity chromatography of homogeneous sIgA on MBP-Sepharose, the fractions eluted with buffer containing 0.15 and $3.0 \mathrm{M} \mathrm{NaCl}$ were not used for further isolation of SIgA against MBP (Figure 4a). The sIgA fractions with high affinity for this sorbent (Abs eluted with acidic buffer) were then additionally separated from possible potential impurities of anti-histone Abs by these sIgA passing through histone5-Sepharose. The Abs eluted from this sorbent during application were used further as anti-MBP sIgA.

The sIgA eluted from MBP-Sepharose during application were used to obtain specific antibodies against 5 histones by affinity chromatography on histone5-Sepharose (Figure $4 \mathrm{~b}$ ). In this case, after elution of sIgA, again, only fractions of eluted acid buffer were used for the following analysis. The sIgA fractions eluted from histone5-Sepharose by acid buffer were additionally passed through MBP-Sepharose. The Abs eluted from MBP-Sepharose during application were used further as anti-histone sIgA. According to the data of affinity chromatography, the $\operatorname{sIg} \mathrm{A}_{\text {mix }}$ preparation contained approximately 1 to $2 \%$ of antibodies, which were eluted from 2 used sorbents together by salts and an acidic buffer.

SDS-PAGE Analysis of Catalytic Cross-reactivity. The unspecific complexation of many proteins with Abs against other similar or foreign ligands (and some enzymes with various compounds) at affinity chromatography is a broadly distributed phenomenon and is known as polyspecificity or polyreactivity complexation of Abs (Zhou et al., 2007; James et al., 2003; James and Tawfik, 2003a,b). The difference in the efficiency of complex formation of specific and unspecific ligands by enzymes and Abs usually does not exceed 1 to 2 orders of magnitude (Nevinsky, 2003, 2011b, 2021; Andreev et al., 2016; Belov et al., 2017). The hydrolysis of proteins by enzymes or abzymes can only occur after their complex formation with such ligands. Canonic enzymes, however, usually catalyze only 1 reaction, and enzyme-dependent catalysis of unspecific ligand conversation (catalytic cross-reactivity) after the formation of nonspecific complexes with them is an extremely unusual and rare case (Nevinsky, 2003, 2011b, 2021). It has been shown that not the formation of a complex of the enzyme with the ligand but the subsequent stages of specific substrate conformation change, and the stage of the catalysis usually directly provides the increase in the reaction rate by 5 to 8 orders of magnitude in the case of specific substrates compared with unspecific substrates. One of the very important factors providing the increase in the reaction rate is

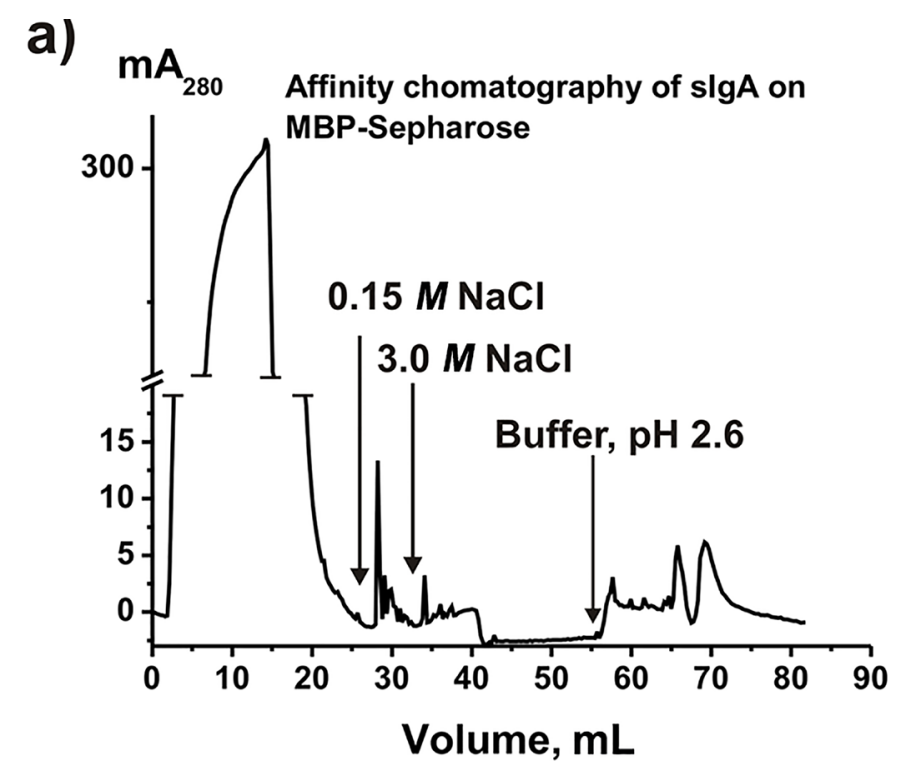

b)

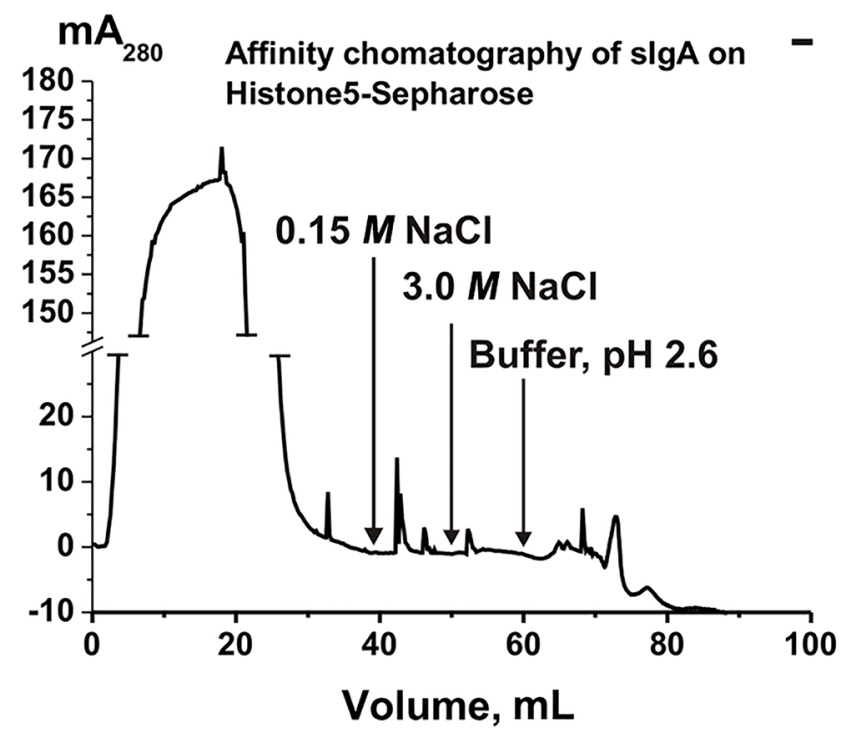

Figure 4. Affinity chromatography of secretory (s) $\operatorname{Ig} \mathrm{A}_{\text {mix }}$ on myelin basic protein (MBP; a) and histone-5-Sepharose (b) (-) optical density $\left(\mathrm{A}_{280}\right) \cdot \mathrm{mA}_{280}=$ milliA $_{280}$. The $\mathrm{NaCl}$ concentrations and acidic buffer used for the elution of antibodies adsorbed by affinity sorbents are shown in the panels. sIgAmix $=$ a mixture of equal amounts of sIgA from 7 human milk samples. 
"orbital control-fitting" of the reacting AA groups of the enzymes and substrates with an accuracy of 10 to $15^{\circ}$, which is possible only for specific substrates (Fersht, 1980). Therefore, in contrast to unspecific complex formation, which is also revealed for some canonical enzymes, catalytic cross-reactivity is an extremely rare case (Nevinsky, 2003, 2011b, 2021). Typically, canonical enzymes catalyze only 1 chemical reaction.

Using several chromatographies of sIgA on MBPSepharose and histone5-Sepharose, homogeneous total sIgA were separated for fractions with a high affinity to MBP (anti-MBP sIgA) and 5 histones (anti-histone sIgA). Electrophoretically homogeneous MBP preparations, unfortunately, were not available (see above). Figure 5a demonstrates that the incubation of a mixture of 5 histones for $5 \mathrm{~h}$ with sIgA against the histones and against $\mathrm{MBP}$ results in their very efficient hydrolysis. Anti-MBP and anti-histones sIgA effectively hydrolyzed MBP (Figure 5b). These data could potentially indicate that anti-MBP and anti-histone sIgA may have not only polyspecificity in complexation with MBP and histones, but also possess catalytic cross-reactivity. These data, however, do not provide absolute evidence of catalytic cross-reactivity between sIgA against MBP and 5 histones because, in spite of their purifications by several affinity chromatographies, it cannot be excluded that obtained sIgA preparations could contain small impurities of alternative Abs. The best evidence of enzymatic cross-catalytic activities may be an obvious difference in the specific sites of the hydrolysis of histones by Abs against these 5 histones and MBP.
MALDI Analysis of H1 Histone Hydrolysis. The fractions with high affinity to 5 histones (antihistones $\operatorname{sIg} \mathrm{A}$ ) and to MBP (anti-MBP sIgA) were used to reveal the cleavage sites of $\mathrm{H} 1, \mathrm{H} 2 \mathrm{~A}$, and $\mathrm{H} 2 \mathrm{~B}$ histones using MALDI-TOF MS. Immediately after the addition of these sIgA (Figure 6a), H1 histone was approximately homogeneous; there were only 2 signals of its 1 - $(\mathrm{m} / z=20,715 \mathrm{Da})$ and 2-charged ions $(\mathrm{m} / z$ $=10,357.5 \mathrm{Da})$. H1 hydrolysis assays were performed with anti-MBP and anti-histone sIgA antibodies after 3,6 , and $24 \mathrm{~h}$ of incubation. Almost all the main peaks corresponding to different sites of $\mathrm{H} 1$ hydrolysis were clearly visible after $6 \mathrm{~h}$ of hydrolysis (Figure $6 \mathrm{~b}$ ). Incubation of mixtures for $24 \mathrm{~h}$ led to complete hydrolysis of $\mathrm{H} 1$ with the formation of very small fragments $(<5$ $\mathrm{kDa})$.

Analysis of MM of all possible sequences of $\mathrm{H} 1$ fragments, which could match the MM corresponding to these peaks, was performed. Finally, from all spectra (3-24 h of the incubation), we have revealed only 1 variant of the reliably identifiable 9 cleavage sites of $\mathrm{H} 1$ in the case of anti-histone SIgA as follows: 14,544.1 (K135-K136), 12,696 (A117-T118), 11,771.4 (T109-K110), 12,498.7 (V75-T76), 11,258.0 (A88-S89), 10,325.6 (K96-S97), 9,983.4 (R93-L94), 6,590.3 (K131A132), and 3,626.3 (P159-K160). All hydrolysis sites for $\mathrm{H} 1$ by anti-histone $\operatorname{sg} \mathrm{A}$ are shown in Figure $6 \mathrm{~d}$.

Due to the analysis of the set of data on $\mathrm{H} 1$ hydrolysis with sIgA against MBP (3-24 h; e.g., Figure $6 \mathrm{c}), 11$ reliably determined peaks of hydrolysis were found (Da) as follows: 18,800.9 (A128-A129), 15,166.5

\section{Hydrolysis of five histones Hydrolysis of myelin basic protein}

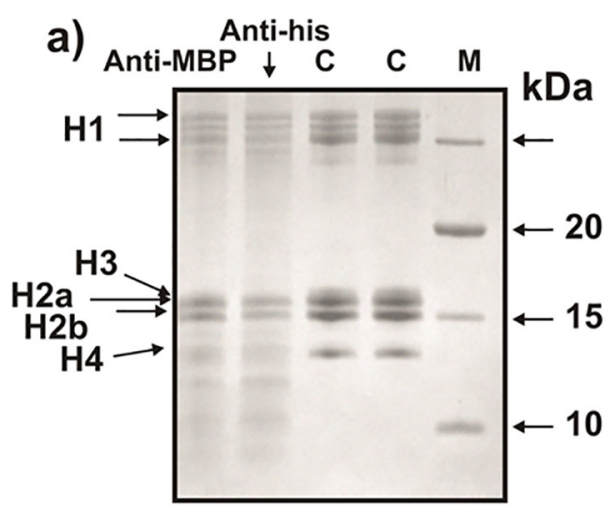

b)

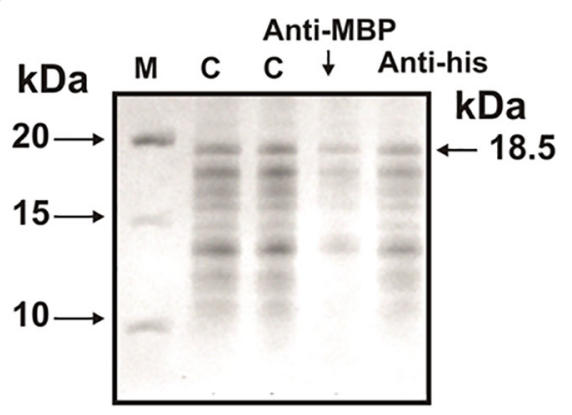

Figure 5. Sodium dodecyl sulfate-PAGE analysis of the relative activity of anti-histones and anti-myelin basic protein (MBP) secretory (s) $\operatorname{IgA}_{\text {mix }}(0.2 \mathrm{mg} / \mathrm{mL})$ purified by affinity chromatography on histone-5-Sepharose and MBP-Sepharose in the hydrolysis of 5 histones (a) and MBP (b) for $5 \mathrm{~h}$ of incubation. Lanes corresponding to different antibodies are indicated on the panels, 2 lanes labeled "C" correspond to 2 controls (incubation of proteins without sIgA). Lanes M correspond to proteins of known molecular weight. sIgAmix $=$ a mixture of equal amounts of sIgA from 7 human milk samples. 
(P141-V142), 14,544.1 (K135-K136), 12,722 (R73-L74), 11,771.4 (T109-K110), 11,414.1 (F106-K107), 11,096 (S97-D98), 10,723 (R93-L94), 9,983.4 (P100-K101), 6,590.3 (K131-A132), and 4,647 (L149-A150).

Interestingly, the main $\mathrm{H} 1$ hydrolysis sites were located mainly in 2 extended clusters from P73 to T118 and from A129 to T161, but they were different. Their location in the case of anti-histone and anti-MBP in these extended clusters was also different. Among the 9 sites of $\mathrm{H} 1$ hydrolysis by Abs against 5 histones and 11 sites of its hydrolysis by anti-MBP sIgA, only 3 sites coincided as follows: P100-K101, K131-A132, and K135-K136. At the same time, according to the averaged data of the analysis of several spectra, K131-A132 was the major site of the hydrolysis of $\mathrm{H} 1$ by both types of $\operatorname{sIg} \mathrm{A}$; the P100-K101 site was minor in the case of Abs against histones, but was the average site for $\operatorname{sig} \mathrm{A}$ against MBP; the reverse situation was observed for the K135-K136 site (Figures 6d and 6e). Thus, sIgA

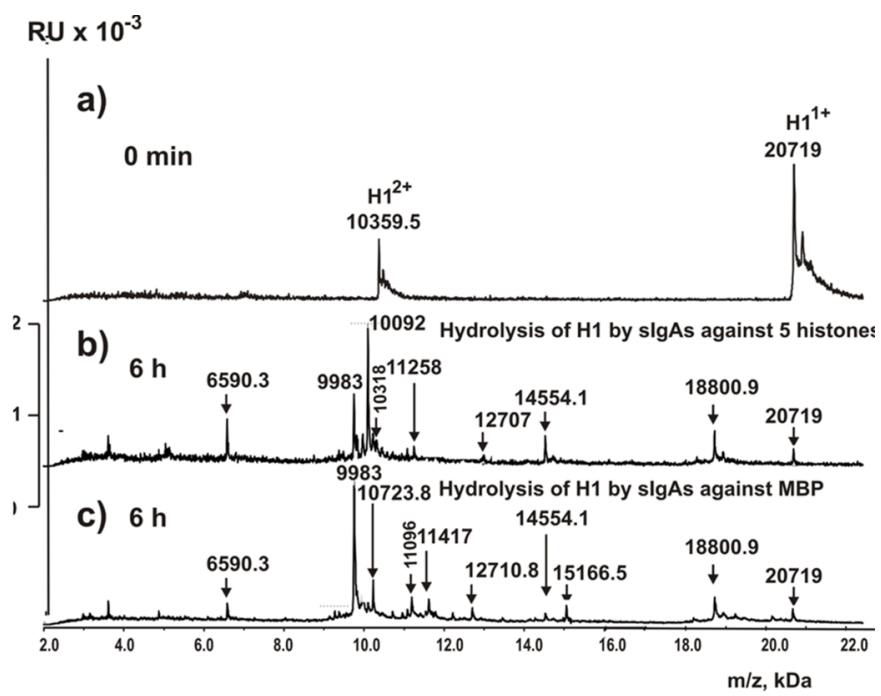

d) Sites of $\mathrm{H} 1$ hydrolysis by sIgAs against histones

1-Tenstsapaakpkrakaskkstdhpkysdmivaaiqaeknragssrqsiqkyikshykvgen-62 63-adsqiklsirlV*TtgvlkqtkgvgA*SgsfrlaK:SdeP*Kksvafkktkkeikkv-115 116-A*TpkkaskpkkaasK $\star A * P t K: K p k a t p v k k a k k k l a a t p k k a k k p K \star T-161$ 162-vkakpvkaskpkkakpvkpkakssakragkkk-193

e) Sites of $\mathrm{H} 1$ hydrolysis by slgAs against MBP

1-Tenstsapaakpkrakaskkstdhpkysdmivaaiqaeknragssrqsiqkyikshykvgen-62 63-adsqiklsikR:LvttgvlkqtkgvgasgsfR:LaksdeP:KkS*VaF*KkT*Kkeik-113 114-kvatpkkaskpkkA:AsK $\star$ AptK*KpkatP*VkkakkkL:Aatpkkakkpkt-161 162-vkakpvkaskpkkakpvkpkakssakragkkk-193

Figure 6. Matrix-assisted laser desorption/ionization (MALDI) mass spectra of $\mathrm{H} 1(0.7 \mathrm{mg} / \mathrm{mL})$ in the absence of antibodies (Abs; a) and its hydrolysis by secretory (s) IgA against 5 histones (b) and by Abs against myelin basic protein (MBP; $0.15 \mathrm{mg} / \mathrm{mL}$; $)$ after $6 \mathrm{~h}$ of the mixture incubation. All sites of $\mathrm{H} 1$ cleavage by anti-histones (d) and anti-MBP (e) antibodies are shown in red. All major sites of cleavage are shown by large stars, moderate site by colons, and minor sites of hydrolysis by asterisks (d, e). The relative magnitude of the signals is given in relative units (RU). against $\mathrm{H} 1$ and MBP possessed not only complexation polyreactivity, but also cross-catalytic activity in the hydrolysis of $\mathrm{H} 1$ histone.

\section{Analysis of Site-Specificity of H2a Histone Hydrolysis}

The sites of H2A hydrolysis were identified using its in-time hydrolysis with sIgA antibodies against 5 different histones (H1-H4) and MBP. These antibodies were eluted with an acidic buffer $(\mathrm{pH}$ 2.6) from specific adsorbents containing immobilized individual histones $\mathrm{H} 1$ to H4. Before the addition of antibodies, the H2A histone corresponded with only singly charged $(\mathrm{m} / z=$ 13,981.9 Da) and doubly charged ions $(\mathrm{m} / z=6,991.0$ Da; Figure 7a). After a 6-h incubation with sIgA against individual histones, a variety of hydrolysis products were found corresponding to 15 different cleavage sites with MM (Da) as follows: 13,126.4 (K9-A10), 12,269 (R17-S18), 11,038.2 (T110-I11), 10,609.9 (R32-L33), 10,227.7 (R35-K36), 9,550.3 (S40-E41), 9,556.4 (R88N89), 9,400.3 (87-R88), 9,109.1 (G46-A47), 8,550.8 (Y50-L51), 8,089.5 (T76-R77), 7,988.4 (K75-T76), 7,151.0 (L63-E64), 5,754.3 (R77-I78), and 4,896.7 (K95-L96) (Figure 7b). After a 24-h incubation, only small $(<5.7 \mathrm{kDa})$ oligopeptides were detected (Figure $7 \mathrm{c}$ ). All sites of $\mathrm{H} 2 \mathrm{~A}$ hydrolysis are given in Figure $7 \mathrm{f}$.

An analysis of the hydrolysis of H2A by anti-MBP antibodies was also carried out. Figure $7 \mathrm{~d}$ and e show the data of MALDI spectra of H2A hydrolysis by these Abs during 6 and $24 \mathrm{~h}$. After the analysis of the MM of the hydrolysis products, the following 18 hydrolysis sites of H2A were established as follows: 13,126.4 (K9A10), 12,899.3 (R11-A12), 12,269 (R17-S18), 11,927.7 (R20-A21), 11,002.2 (R29-V30), 10,609.9 (R32-L33), 10,227.7 (R35-K36), 9,550.3 (S40-E41), 9,400.3 (I87R88), 8,678.9 (Y57-L58), 8,245.5 (R77-I78), 8,082.6 (E56-Y57), 7,151.0 (I63-E64), 6,496.7 (R71-D72), 5,275.0 (R81-H82) 5024.8 (L83-Q84), 4,896.7 (L83Q84), and 4,890.7 (G46-A47). All sites of H2A hydrolysis by anti-MBP antibodies are given in Figure $7 \mathrm{~g}$.

Among the 15 and 18 sites of H2A hydrolysis by antibodies against histones and MBP, respectively, only 10 sites coincided; 5 and 8 sites, respectively, of H2A hydrolysis were different. Moreover, the efficiency of cleavage at 10 coinciding sites by anti-histones and anti-MBP antibodies occurred with very different efficiency. In addition, in the case of antibodies against histones, 3 major hydrolysis sites were found as follows: R32-L33, R77-I78, and L83-Q84. However, 2 other major cleavage sites were found for Abs against MBP as follows: R20-A21 and R81-H82. Thus, we found that sIgA against histone $\mathrm{H} 2 \mathrm{~A}$ and against MBP have not only the ability to form complexes with histone $\mathrm{H} 2 \mathrm{~A}$, 
but can also hydrolyze this histone, exhibiting catalytic cross-reactivity.

\section{Analysis of Site-specificity of H2B Histone Hydrolysis}

Figure 8a demonstrates that before addition of sIgA, H2B was approximately homogeneous, showing its 1 $(\mathrm{m} / z=13,780.6 \mathrm{Da})$ - and 2-charged ions $(\mathrm{m} / z=6,890.2$ Da). After 3 and $6 \mathrm{~h}$ of the incubation with anti-histones, sIgA (Figure 8b and c) revealed many peaks corresponding to 12 different sites of histone-splitting with MM (Da) as follows: 13,377.3 (K120-Y121), 12,521.8 (G13-S14), 11,779.3 (K20-A21), 10,739.7 (R29-K30),

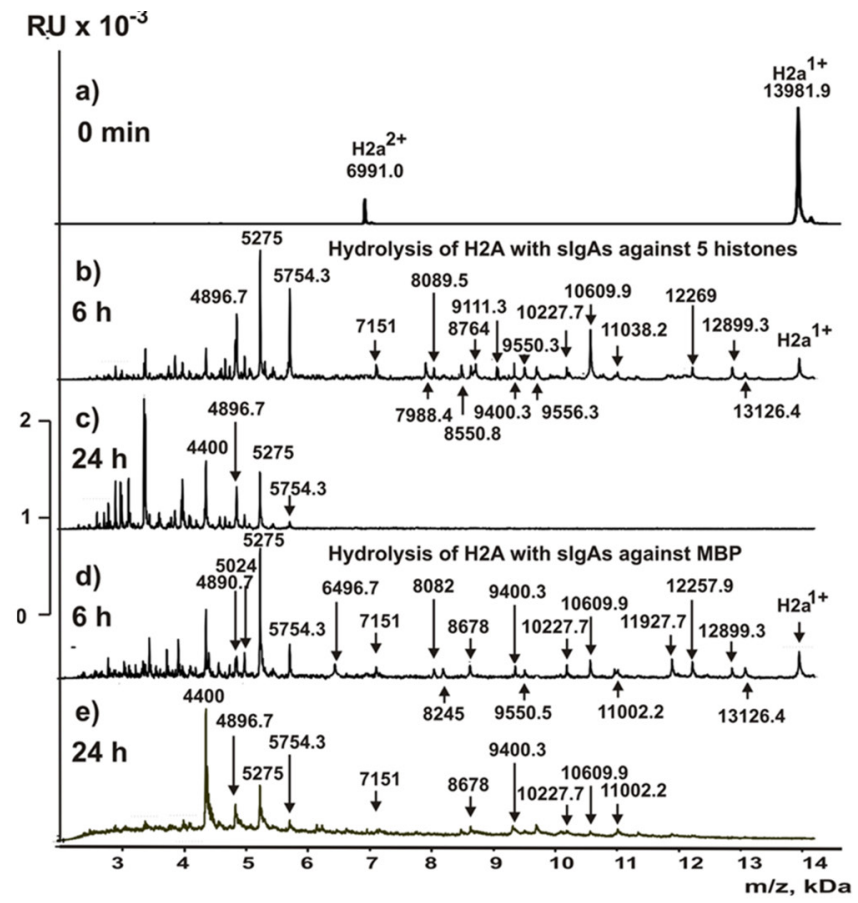

f) Sites of $\mathrm{H} 2 \mathrm{~A}$ hydrolysis by sIgAs against histones

1-sgrgkqggK*ArakaksR*SsraglqfpvgrvhR $\star \mathrm{LIR}^{*} \mathrm{KgnyS}^{*} \mathrm{ErvG}^{*} \mathrm{~A}-45$ 46-gapv $Y^{*}$ LaavleyltaeiL ${ }^{*}$ ElagnaardnkK ${ }^{*} T * R \star \operatorname{IiprhL} \star \star Q \mathrm{QlaI}{ }^{*} \mathrm{R} * \mathrm{~N}-89$ 90-deelnK*LlgrvT*Iaqggvlpniqavllpkkteshhkakgk-129

\section{g) Sites of H2A hydrolysis by slgAs against MBP}

1-sgrgkgggK:AR:AkaksR:SsR ^ AglgfpvgR:VhR:LIR:KgnyS:Ervga-45 46-G:ApvY:LaavlE*YltaeI*ElagnaA*R*DnkktR*IipR $\star$ HL:QlaI:Rn-89 90-deelnkllgrvtiagggvlpniaavllpkkteshhkakgk-129

Figure 7. Matrix-assisted laser desorption/ionization (MALDI) mass spectra of $\mathrm{H} 2 \mathrm{~A}(0.7 \mathrm{mg} / \mathrm{mL})$ in the absence of antibodies (Abs; a) and its hydrolysis by secretory (s)IgA against 5 histones during 6 and $24 \mathrm{~h} \mathrm{(b}$ and $\mathrm{c}$ ) as well as by Abs against myelin basic protein (MBP; $0.15 \mathrm{mg} / \mathrm{mL}$; d and e) after 6 and $24 \mathrm{~h}$ of the mixtures incubation. All sites of H2A cleavage by anti-histones (f) and anti-MBP (g) antibodies are shown in red. All major sites of cleavage are shown by large stars, moderate site by colons, and minor sites of hydrolysis by asterisks ( $\mathrm{f}$ and $\mathrm{g}$ ). The relative magnitude of the signals is given in relative units (RU).
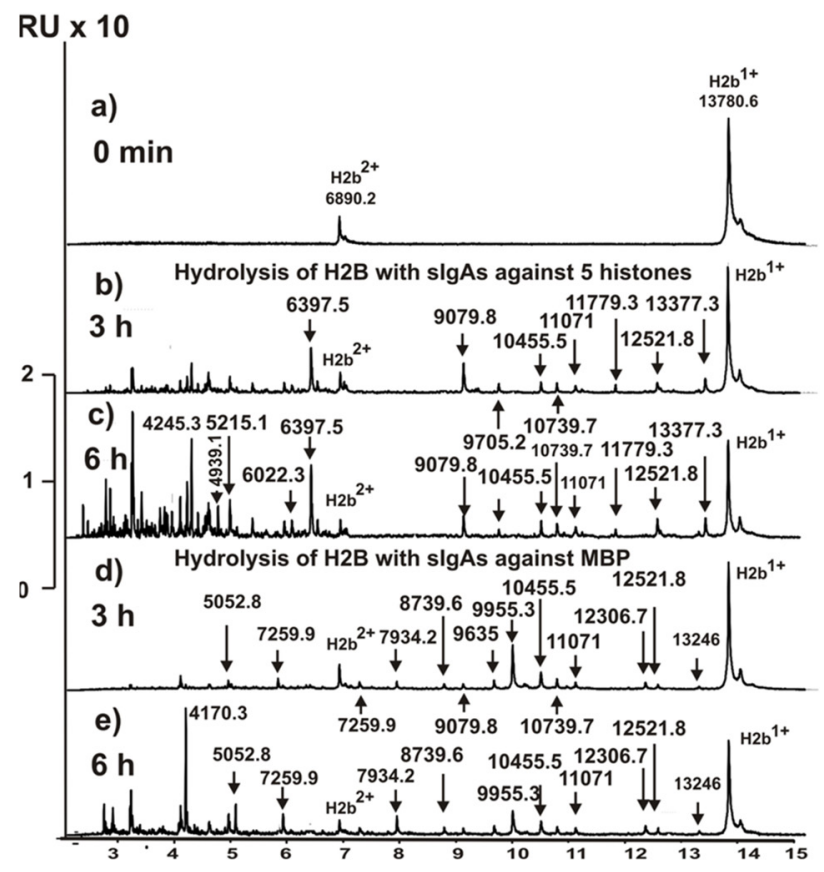

f) Sites of H2B hydrolysis by slgAs against histones

1-PepaksapapkkG:SkkavtK:AqkkdgkkR*KR:SrkesY*SiY:VY:Kv-44 lkQ:VhpdtgisskamgimnsfvN $\star D i F: E r i a g e a s r L ~ \star A h y n k r s \underline{t i t s r e}$ 94-iqtavrlllpgelakhavsegtkavtK:Ytssk-125

\section{g) Sites of H2B hydrolysis by slgAs against MBP}

1-pepaksapapkkG*SK*KavtkaqkkdgkkR*KR:SrkE $\star S y S * I y v Y * K v-44$ 45-L*KqvhpdT:GisskaM*GimnsfvN $\star$ DiferiageasR:Lah $Y^{*} \mathbf{N}^{*} \mathrm{~K}^{*} \mathrm{R} *$ Stitsre-92 94-iatavR*Lllpgelakhavsegtkavtkvtssk-125

Figure 8. Matrix-assisted laser desorption/ionization (MALDI) mass spectra of $\mathrm{H} 2 \mathrm{~B}(0.7 \mathrm{mg} / \mathrm{mL})$ in the absence of antibodies (Abs; a) and its hydrolysis by secretory (s) IgA against 5 histones during 3 and $6 \mathrm{~h}$ (b and $\mathrm{c}$ ) and by Abs against myelin basic protein (MBP; 0.15 $\mathrm{mg} / \mathrm{mL}$; d and e) after 3 and $6 \mathrm{~h}$ of incubation. All sites of H2B cleavage by anti-histones (f) and anti-MBP (g) antibodies are shown in red. The relative magnitude of the signals is given in relative units (RU) All major sites of cleavage are shown by large stars, moderate site by colons, and minor sites of hydrolysis by asterisks ( $\mathrm{f}$ and $\mathrm{g}$ ).

10,455.5 (R31-S32), 9,705.2 (Y37-S38), 9,079.8 (Y42K43), 6,397.5 (N67-D68), 6,022.3 (F70-E71), 5,315.1 (Q47-V48), and 4,939.7 (L80-A81). All sites of H2B cleavage by anti-histone sIgA are given in Figure 8f.

Figure 8d and e demonstrate MALDI spectra of H2B cleavage by sIgA against MBP after incubation of mixtures for 3 and $6 \mathrm{~h}$. Seventeen sites of H2B cleavage were revealed as follows: 12,521.8 (G13-S14), 12,521.8 (15K-14K), 11,071.0 (R99-L100), 10,739.7 (R29-K30), 10,455.5 (R31-S32), 9,955.3 (E35-S36), 9,618.1 (S38I39), 9,079.8 (Y42-K43), 8,739.6 (L45-K46), 7,934.2 (T52-G53), 7,259.9 (M59-G60), 6,397.5 (N67-D68), 5,052.8 (R79-L80), 4,568.5 (Y83-N84), and (R86-S87). All sites of H2B hydrolysis by SIgA against MBP are given in Figure 8g. 
Among 12 sites corresponding to the hydrolysis of H2B by anti-histone sIgA, only 5 of them coincided with the same 5 sites that corresponded to 17 sites of histone-splitting by anti-MBP antibodies (Figure 8g). Moreover, only 1 site (N67-D68) was simultaneously a major site for these 2 types of Abs, whereas the other 2 major sites, L80-A81 (anti-histones Abs) and E37S38 (Abs against MBP), did not coincide. In general, sIgA against MBP are able to bind to histone H2B and hydrolyze it mainly at other sites than antibodies against $\mathrm{H} 2 \mathrm{~B}$.

\section{DISCUSSION}

In this study, we first analyzed the activity of $\operatorname{sig} \mathrm{A}$ from human milk in the hydrolysis of MBP and 5 histones. We observed that 7 sIgA effectively hydrolyzed both proteins. However, the relative activities of $\operatorname{sIgA}$ in the hydrolysis of these proteins are dependent on the preparations.

The nonspecific interaction of a large number of compounds with antibodies against foreign antigens is a widespread phenomenon (James et al., 2003; James and Tawfik, 2003a,b; Zhou et al., 2007). Canonical specific enzymes usually catalyze only 1 chemical reaction (Nevinsky, 2003, 2011b, 2021). All auto-abzymes described to date against many different proteins can hydrolyze only their specific proteins (Nevinsky and Buneva, 2003, 2005; Nevinsky, 2010, 2011, 2016, 2017). Therefore, it was difficult to suppose that the abzymes against the 5 histones (H1-H4) and MBP exhibited cross-reactivity. The first examples of autoantibodies with catalytic cross-activity were antibodies against MBP and IgG against 5 histones (H1, H2A, H2B, H3, and $\mathrm{H} 4$ ) in HIV-infected patients (Baranova et al., 2019a, 2020, 2021). Therefore, we analyzed the possible cross-activity of sIgA antibodies from human milk. Using several affinity chromatographies, sIgA antibodies against 5 histones and MBP were isolated. Indisputable evidence of cross-enzymatic activity of sIgA antibodies against histones and MBP can be obtained only from comparing the sites of hydrolysis of histones and MBP by antibodies against these proteins. The data obtained using MALDI MS unambiguously indicated not only the polyreactivity of complexation but also the cross-catalytic activity of milk sIgA against histones and MBP.

Among the 9 sites of $\mathrm{H} 1$ hydrolysis by sIgA against 5 histones, only 3 sites (P100-K101, K131-A132, and K135-K136) coincided with 3 of 11 sites of hydrolysis by anti-MBP sIgA (Figure 6). Ten of 15 and 18 sites of H2A splitting by sIgA against histones and MBP, respectively, were the same. However, the relative efficiency of 10 sites with cleavage anti-histones and
anti-MBP antibodies was very different. In addition, in the case of $\operatorname{sIg} \mathrm{A}$ against histones and MBP, we found different sites of major cleavage (Figure 7).

Only 5 sites corresponding to 12 sites of H2B hydrolysis by anti-histone $\operatorname{sIgA}$ were the same as in the case of 17 sites of this histone hydrolyzed by anti-MBP antibodies (Figure 8g). In addition, only 1 site (N67D68) was major for 2 types of sIgA, whereas several others were different. An interesting feature is that anti-MBP sIgA hydrolyze 3 histones at more sites than abzymes against the histones themselves. This may be because the clusters of the main MBP hydrolysis sites correspond to very different protein sequences. Anti-MBP antibodies were found mainly in 4 antigenic determinants localized in different parts of this protein (Baranova et al., 2019a). At the same time, all sequences of the 4 hydrolysis clusters of MBP in the case of anti-MBP abzymes have a high level of homology with the sequences of histones in which they are hydrolyzed by antibodies against individual 5 histones (Baranova et al., 2019a, 2020, 2021). Earlier, it was concluded that in the case of IgG of HIV-infected patients, the cross-catalytic activity of antibodies against MBP and histones is a consequence of the high level of homology between the sequences of MBP, hydrolyzed by anti-MBP antibodies, and surface histone sequences available for complexation and hydrolysis by anti-MBP abzymes (Baranova et al., 2019a, 2020, 2021).

It is known that many human proteins have a high level of homology with the proteins of some viruses and bacteria harmful to humans (Nevinsky, 2010, 2011a, 2016, 2017; Baranova et al., 2019a, 2020, 2021). One of the reasons for hydrolysis by antibodies against histones and MBP is the high level of homology of these proteins. Thus, it cannot be ruled out that antibodies against histones and MBP can hydrolyze some proteins of viruses and bacteria harmful to humans, thus protecting babies from certain infections. Taken together, it was first shown that milk sIgA against histones and against MBP similar to IgG from sera of HIV-infected patients demonstrate not only cross-complexation but also catalytic cross-reactivity.

The MBP- and histone-hydrolyzing abzymes have been detected in the blood sera of patients with multiple sclerosis (Polosukhina et al., 2004; Baranova et al., 2019b), SLE (Bezuglova et al., 2011), schizophrenia (Parshukova et al., 2019; Ermakov et al., 2020), and HIV infection (Baranova et al., 2016, 2017a,b, 2018, 2019a, 2020, 2021). As mentioned above, fresh human milk contains many different abzymes with typical and unusual functions that are not present in the blood of patients with various autoimmune diseases. The data of this work indicated that human milk also contains abzymes that hydrolyze MBP and histones. 


\section{CONCLUSIONS}

We have shown here for the first time that $\operatorname{sig} \mathrm{A}$ in breast milk exhibits cross-catalytic activity in the hydrolysis of MBP and 5 histones. The high activity of human milk abzymes is most likely a part of the restructuring by the specific immune memory of the immune system of pregnant and lactating women, leading to the production of many unusual autoantibodies and abzymes. Only the $\operatorname{sg} \mathrm{A}$ and $\operatorname{IgG}$ abzymes of human milk have several unique enzymatic activities, including the phosphorylation of oligosaccharides, proteins, and lipids. The biological role of these unique IgG and $\operatorname{sg} \mathrm{A}$ abzymes, which hydrolyze MBP and histones, in protecting infants from various harmful factors is not yet clear. However, it should be assumed that the appearance of such abzymes in human milk is not accidental. Thus, the analysis of the biological function of milk antibodies seems to be very important.

\section{ACKNOWLEDGMENTS}

This study was supported by the Russian Science Foundation (no. 19-15-00145; Moscow, Russia) and the grant of Russian State-funded budget project AAAAA17-117020210023-1 (salary for work performers; Novosibirsk, Russia). The authors have not stated any conflicts of interest.

\section{REFERENCES}

Alroughani, R., M. S. Alowayesh, S. F. Ahmed, R. Behbehani, and J. Al-Hashel. 2018. Relapse occurrence in women with multiple sclerosis during pregnancy in the new treatment era. Neurology 90:e840-e846. https://doi.org/10.1212/WNL.0000000000005065.

Amino, N., H. Mori, Y. Iwatani, O. Tanizawa, M. Kawashima, I. Tsuge, K. Ibaragi, Y. Kumahara, and K. Miyai. 1982. High prevalence of transient post-partum thyrotoxicosis and hypothyroidism. N. Engl. J. Med. 306:849-852. https://doi.org/10.1056/ NEJM198204083061405.

Andreev, S. L., V. N. Buneva, and G. A. Nevinsky. 2016. How human IgGs against DNA recognize oligonucleotides and DNA. J. Mol. Recognit. 29:596-610. https://doi.org/10.1002/jmr.2559.

Andrievskaya, O. A., V. N. Buneva, A. G. Baranovskii, A. V. Gal'vita, E. S. Benzo, V. A. Naumov, and G. A. Nevinsky. 2002. Catalytic diversity of polyclonal RNA-hydrolyzing IgG antibodies from the sera of patients with systemic lupus erythematosus. Immunol. Lett. 81:191-198. https://doi.org/10.1016/S0165-2478(02)00006-8.

Andrievskaya, O. A., V. N. Buneva, V. A. Naumov, and G. A. Nevinsky. 2000. Catalytic heterogenity of polyclonal RNA-hydrolyzing IgM from sera of patients with lupus erythematosus. Med. Sci. Monit. 6:460-470

Andryushkova, A. A., I. A. Kuznetsova, I. A. Orlovskaya, V. N. Buneva, and G. A. Nevinsky. 2006. Antibodies with amylase activity from the sera of autoimmune-prone MRL/MpJ-lpr mice. FEBS Lett. 580:5089-5095. https://doi.org/10.1016/j.febslet.2006.08 .036 .

Andryushkova, A. A., I. A. Kuznetsova, V. N. Bineva, L. B. Toporkova, L. V. Sakhno, M. A. Tikhonova, E. R. Chernykh, I. A. Orlovskaya, and G. A. Nevinsky. 2007. Formation of different abzymes in autoimmune-prone MRL-lpr/lpr mice is associated with changes in colony formation of haematopoetic progenitors. J. Cell. Mol. Med. 11:531-551. https://doi.org/10.1111/j.1582-4934.2007.00048.x.

Aulova, K. S., L. B. Toporkova, J. A. Lopatnikova, A. A. Alshevskaya, S. E. Sedykh, V. N. Buneva, T. Budde, S. G. Meuth, N. A. Popova, I. A. Orlovskaya, and G. A. Nevinsky. 2018. Changes in cell differentiation and proliferation lead to production of abzymes in EAE mice treated with DNA-Histone complexes. J. Cell. Mol. Med. 22:5816-5832. https://doi.org/10.1111/jcmm.13850.

Baalbaki, S., J. M. Szychowski, Y. Tang, L. Wetta, A. Subramaniam, and J. Ochsner. 2020. Systemic Lupus Erythematosus: Perinatal outcomes in patients treated with and without hydroxychloroquine. 20:362-367. https://doi.org/10.31486/toj.20.0013.

Bakos, M. A., A. Kurosky, and R. M. Goldblum. 1991. Characterization of a critical binding site for human polymeric Ig on secretory component. J. Immunol. 147:3419-3426.

Baranova, S. V., V. N. Buneva, M. A. Kharitonova, L. P. Sizyakina, C. Calmels, M. L. Andreola, V. Parissi, and G. A. Nevinsky. 2009. HIV-1 integrase-hydrolyzing antibodies from sera of HIV-infected patients. Biochimie 91:1081-1086. https://doi.org/10.1016/j .biochi.2009.06.018.

Baranova, S. V., V. N. Buneva, and G. A. Nevinsky. 2016. Antibodies from the sera of HIV-infected patients efficiently hydrolyze all human histones. J. Mol. Recognit. 29:346-362. https://doi.org/10 $.1002 / \mathrm{jmr} .2534$.

Baranova, S. V., P. S. Dmitrienok, V. N. Buneva, and G. A. Nevinsky. 2019a. Autoantibodies in HIV-infected patients: Cross site-specific hydrolysis of $\mathrm{H} 1$ histone and myelin basic protein. Biofactors 45:211-222. https://doi.org/10.1002/biof.1473.

Baranova, S. V., P. S. Dmitrienok, V. N. Buneva, and G. A. Nevinsky. 2020. HIV-infected patients: Cross site-specific hydrolysis of H2a and $\mathrm{H} 2 \mathrm{~b}$ histones and myelin basic protein with antibodies against these three proteins. biomolecules 10:1501. https://doi.org/10 $.3390 /$ biom10111501

Baranova, S. V., P. S. Dmitrenok, V. N. Buneva, S. E. Sedykh, and G. A. Nevinsky. 2021. HIV-infected patients: Cross site-specific hydrolysis of $\mathrm{H} 3$ and $\mathrm{H} 4$ histones and myelin basic protein with antibodies against these three proteins. Molecules 26:316. https:// doi.org/10.3390/molecules26020316.

Baranova, S. V., P. S. Dmitrienok, N. V. Ivanisenko, V. N. Buneva, and G. A. Nevinsky. 2017a. Antibodies to H1 histone from the sera of HIV-infected patients recognize and catalyze site-specific degradation of this histone. J. Mol. Recognit. 30:e2588. https:// doi.org/10.1002/jmr.2588.

Baranova, S. V., P. S. Dmitrienok, N. V. Ivanisenko, V. N. Buneva, and G. A. Nevinsky. 2017b. Antibodies to H2a and H2b histones from the sera of HIV-infected patients catalyze site-specific degradation of these histones. Mol. Biosyst. 13:1090-1101. https://doi .org/10.1039/C7MB00042A

Baranova, S. V., P. S. Dmitrenok, A. D. Zubkova, N. V. Ivanisenko, E. S. Odintsova, V. N. Buneva, and G. A. Nevinsky. 2018. Antibodies against $\mathrm{H} 3$ and $\mathrm{H} 4$ histones from the sera of HIV-infected patients catalyze site-specific degradation of these histones. J. Mol. Recognit. 31:e2703. https://doi.org/10.1002/jmr.2703.

Baranova, S. V., E. V. Mikheeva, V. N. Buneva, and G. A. Nevinsky. 2019b. Antibodies from the sera of multiple sclerosis patients efficiently hydrolyze five histones. Biomolecules 9:741. https://doi .org/10.3390/biom9110741.

Baranovskii, A. G., T. G. Kanyshkova, A. S. Mogelnitskii, V. A. Naumov, V. N. Buneva, E. I. Gusev, A. N. Boiko, T. A. Zargarova, O. O. Favorova, and G. A. Nevinsky. 1998. Polyclonal antibodies from blood and cerebrospinal fluid of patients with multiple sclerosis effectively hydrolyze DNA and RNA. Biochemistry (Mosc.) 63:1239-1248.

Baranovsky, A. G., V. G. Matushin, A. V. Vlassov, V. G. Zabara, V. A. Naumov, R. Giege, V. N. Buneva, and G. A. Nevinsky. 1997. DNA- and RNA-hydrolyzing antibodies from the blood of patients with various forms of viral hepatitis. Biochemistry (Mosc.) 62:1358-1366.

Belov, S., V. N. Buneva, and G. A. Nevinsky. 2017. How human IgGs against myelin basic protein (MBP) recognize oligopeptides and 
MBP. J. Mol. Recognit. 30:e2637. https://doi.org/10.1002/jmr 2637.

Bezuglova, A. M., L. P. Konenkova, B. M. Doronin, V. N. Buneva, and G. A. Nevinsky. 2011. Affinity and catalytic heterogeneity and metal-dependence of polyclonal myelin basic protein-hydrolyzing IgGs from sera of patients with systemic lupus erythematosus. J. Mol. Recognit. 24:960-974. https://doi.org/10.1002/jmr.1143.

Buneva, V. N., T. G. Kanyshkova, A. V. Vlassov, D. V. Semenov, D. Y. Khumankov, L. R. Breusova, and G. A. Nevinsky. 1998. Catalytic DNA- and RNA-hydrolyzing antibodies from milk of healthy human mothers. Appl. Biochem. Biotechnol. 75:63-76. https://doi .org/10.1007/BF02787709.

Buneva, V. N., A. N. Kudryavtseva, A. V. Gal'vita, V. V. Dubrovskaya, O. V. Khokhlova, I. A. Kalinina, V. A. Galenok, and G. A. Nevinsky. 2003. Dynamics of antibody nuclease activity in blood of women during pregnancy and lactation. Biochemistry (Mosc.) 68:890-900. https://doi.org/10.1023/A:1025703132523.

Chen, R., R. Kang, X.-G. Fan, and D. Tang. 2014. Release and activity of histone in diseases. Cell Death Dis. 5:e1370. https://doi.org/10 $.1038 /$ cddis.2014.337.

Dayan, C. M., and G. H. Daniels. 1996. Chronic autoimmune thyroiditis. N. Engl. J. Med. 335:99-107.

De Leo, S., and E. N. Pearce. 2018. Autoimmune thyroid disease during pregnancy. Lancet Diabetes Endocrinol. 6:575-586. https:// doi.org/10.1016/S2213-8587(17)30402-3.

Doronin, V. B., T. A. Parkhomenko, A. Korablev, L. B. Toporkova, J. A. Lopatnikova, A. A. Alshevskaja, S. V. Sennikov, V. N. Buneva, T. Budde, S. G. Meuth, I. A. Orlovskaya, N. A. Popova, and G. A. Nevinsky. 2016. Changes in different parameters, lymphocyte proliferation and hematopoietic progenitor colony formation in EAE mice treated with myelin oligodendrocyte glycoprotein. J. Cell. Mol. Med. 20:81-94. https://doi.org/10.1111/jcmm.12704.

Ermakov, E. A., D. A. Parshukova, G. A. Nevinsky, and V. N. Buneva. 2020. Natural catalytic IgGs hydrolyzing histones in schizophrenia: Are they the link between humoral immunity and inflammation? Int. J. Mol. Sci. 21:7238. https://doi.org/10.3390/ijms21197238.

Eudy, A. M., A. M. Siega-Riz, S. M. Engel, N. Franceschini, A. G. Howard, M. E. B. Clowse, and M. Petri. 2018. Effect of pregnancy on disease flares in patients with systemic lupus erythematosus. Ann. Rheum. Dis. 77:855-860. https://doi.org/10.1136/ annrheumdis-2017-212535.

Fersht, A. 1980. Enzyme Structure and Mechanism, Freeman and Co.

Fey, H., R. Bütler, and F. Marti. 1973. The production in the pregnant cow of anti-human immunoglobulin to be used for the antiglobulin test. Vox Sang. 25:245-253. https://doi.org/10.1111/j.1423-0410 1973.tb04369.x.

Freeman, R., H. Rosen, and B. Thysen. 1986. Incidence of thyroid dysfunction in an unselected postpartum population. Arch. Intern. Med. 146:1361-1364. https://doi.org/10.1001/archinte.1986 .00360190137019

Gorbunov, D. V., N. A. Karataeva, V. N. Buneva, and G. A. Nevinsky. 2005. Lipid kinase activity of antibodies from milk of clinically healthy human mothers. Biochim. Biophys. Acta Mol. Cell Biol. Lipids 1735:153-166. https://doi.org/10.1016/j.bbalip.2005 .06 .007 .

Gorbunov, D. V., D. V. Semenov, M. V. Shipitsin, Yu. Yu. Kit, T. G. Kanyshkova, V. N. Buneva, and G. A. Nevinsky. 2000. Phosphorylation of minor lipids of human milk tightly bound to secretory immunoglobulin A. Russ. J. Immunol. 5:267-278.

Hanson, L. A., B. Carlsson, and J. R. Cruz. 1979. T cell regulation of IgA synthesis. Pages 145-157 in Immunology of Breast Milk. P. L. Ogra and D.H. Dayton, eds. Raven Press.

Hanson, L. A., M. Hahn-Zoric, M. Berndes, R. Ashraf, V. Herias, F. Jalil, T. I. Bhutta, A. Laeeq, and I. Mattsby-Baltzer. 1994. Breast feeding: Overview and breast milk immunology. Pediatr. Int. 36:557-561. https://doi.org/10.1111/j.1442-200X.1994.tb03246.x.

Hazes, J. M. 1991. Pregnancy and its effect on the risk of developing rheumatoid arthritis. Ann. Rheum. Dis. 50:71-72. https://doi.org/ 10.1136/ard.50.2.71.
James, L. C., P. Roversi, and D. S. Tawfik. 2003. Antibody multispecificity mediated by conformational diversity. Science 299:13621367. https://doi.org/10.1126/science.1079731.

James, L. C., and D. S. Tawfik. 2003a. Conformational diversity and protein evolution-a 60-year-old hypothesis revisited. Trends Biochem. Sci. 28:361-368. https://doi.org/10.1016/S0968 -0004(03)00135-X.

James, L. C., and D. S. Tawfik. 2003b. The specificity of cross-reactivity: promiscuous antibody binding involves specific hydrogen bonds rather than nonspecific hydrophobic stickiness. Protein Sci. 12:2183-2193. https://doi.org/10.1110/ps.03172703.

Jerne, N. K. 1974. Towards a network theory of the immune system. Ann. Immunol. (Paris) 125C:373-389.

Kalaga, R., L. Li, J. R. O'Dell, and S. Paul. 1995. Unexpected presence of polyreactive catalytic antibodies in IgG from unimmunized donors and decreased levels in rheumatoid arthritis. J. Immunol. 155:2695-2702.

Karataeva, N. A., V. N. Buneva, and G. A. Nevinsky. 2006b. Polysaccharide kinase activity of human milk IgG antibodies. Biochemistry (Mosc.) 71:1207-1221. https://doi.org/10.1134/ S000629790611006X.

Karataeva, N. A., D. Gorbunov, I. V. Prokudin, V. N. Buneva, A. A. Kulminskaya, K. N. Neustroev, and G. A. Nevinsky. 2006a. Human milk antibodies with polysaccharide kinase activity. Immunol. Lett. 103:58-67. https://doi.org/10.1016/j.imlet.2005.10.009.

Kattah, A. G., and V. D. Garovic. 2015. Pregnancy and lupus nephritis. Semin. Nephrol. 35:487-499. https://doi.org/10.1016/j .semnephrol.2015.08.010.

Keinan, E. 2005. Pages 1-586 in Catalytic antibodies. Wiley-VCH Verlag $\mathrm{GmbH}$ and Co. KgaA.

Kit, YYa., D. V. Semenov, and G. A. Nevinsky. 1996. Phosphorylation of different human milk proteins by human catalytic secretory immunoglobulin A. IUBMB Life 39:521-527. https://doi.org/10 $.1080 / 15216549600201571$.

Kompaneets, I. Y., E. A. Ermakov, S. E. Sedykh, V. N. Buneva, and G. A. Nevinsky. 2020a. IgGs from human milk hydrolyze microRNAs. Molecules 25:2366. https://doi.org/10.3390/molecules25102366.

Kompaneets, I. Y., E. A. Ermakov, S. E. Sedykh, V. N. Buneva, and G. A. Nevinsky. 2020b. Secretory immunoglobulin A from human milk hydrolyzes microRNA. J. Dairy Sci. 103:6782-6797. https:// doi.org/10.3168/jds.2019-17823.

Lacroix-Desmazes, S., A. Moreau, C. Sooryanarayana, C. Bonnemain, N. Stieltjes, A. Pashov, Y. Sultan, J. Hoebeke, M. D. Kazatchkine, and S. V. Kaveri. 1999. Catalytic activity of antibodies against factor VIII in patients with hemophilia A. Nat. Med. 5:1044-1047. https://doi.org/10.1038/12483.

Li, L., S. Paul, S. Tyutyulkova, M. D. Kazatchkine, and S. Kaveri. 1995. Catalytic activity of anti-thyroglobulin antibodies. J. Immunol. 154:3328-3332

Mestecky, J., M. W. Russell, S. Jackson, and T. A. Brown. 1986. The human IgA system: A reassessment. Clin. Immunol. Immunopathol. 40:105-114. https://doi.org/10.1016/0090-1229(86)90073 -5 .

Moroni, G., and C. Ponticelli. 2016. Pregnancy in women with systemic lupus erythematosus (SLE). Eur. J. Intern. Med. 32:7-12. https://doi.org/10.1016/j.ejim.2016.04.005.

Neustoev, K. N., D. R. Ivanen, A. A. Kulminskaya, I. H. Brumer, A. N. Saveliev, and G. A. Nevinsky. 2003. Amylolytic activity and catalytic properties of IgM and IgG antibodies from patients with systemic lupus erythematosus. Hum. Antibodies 12:31-34.

Nevinsky, G. A. 2003. Structural, thermodynamic, and kinetic basis of DNA and RNA-dependent enzymes functioning: Important role of weak nonspecific additive interactions between enzymes and long nucleic acids for their recognition and transformation. Pages 133222 in Protein Structures: Kaleidoscope of Structural Properties and Functions. V.N. Uversky, ed. Research Signpost.

Nevinsky, G. A. 2010. Natural catalytic antibodies in norm and in autoimmune diseases. Pages 1-107 in Autoimmune Diseases: Symptoms, Diagnosis and Treatment. K. J. Brenner, ed. Nova Science Publishers, Inc. 
Nevinsky, G. A. 2011a. Natural catalytic antibodies in norm and in HIV-infected patients. Pages 151-192 in Understanding HIV/ AIDS Management and Care-Pandemic Approaches in the 21st Century. F. H. Kasenga, ed. InTech.

Nevinsky, G. A. 2011b. Structural, thermodynamic, and kinetic basis for the activities of some nucleic acid repair enzymes. J. Mol. Recognit. 24:656-677. https://doi.org/10.1002/jmr.1096.

Nevinsky, G. A. 2016. Autoimmune processes in multiple sclerosis: Production of harmful catalytic antibodies associated with significant changes in the hematopoietic stem cell differentiation and proliferation. Pages 100-147 in Multiple Sclerosis. A. ConzalezQuevedo, ed. InTech.

Nevinsky, G. A. 2017. Catalytic antibodies in norm and systemic lupus erythematosus. Pages 41-101 in Lupus. W. A. Khan, ed. InTech.

Nevinsky, G. A. 2021. How enzymes, proteins, and antibodies recognize extended DNAs. Int. J. Mol. Sci. 22:1369. https://doi.org/10 .3390/ijms22031369.

Nevinsky, G. A., and V. N. Buneva. 2003. Catalytic antibodies in healthy humans and patients with autoimmune and viral diseases. J. Cell. Mol. Med. 7:265-276. https://doi.org/10.1111/j.1582-4934 2003.tb00227.x

Nevinsky, G. A., and V. N. Buneva. 2005. Natural catalytic antibodies - abzymes. Pages 505-569 in Catalytic Antibodies. E. Keinan, ed. VCH-Wiley Press.

Nevinsky, G. A., Y. Y. Kit, D. V. Semenov, D. Y. Khumankov, and V. N. Buneva. 1998. Secretory immunoglobulin A from human milk catalyses milk protein phosphorylation. Appl. Biochem. Biotechnol. 75:77-91. https://doi.org/10.1007/BF02787710.

Parshukova, D., L. P. Smirnova, E. A. Ermakov, N. A. Bokhan, A. V. Semke, S. A. Ivanova, V. N. Buneva, and G. A. Nevinsky. 2019. Autoimmunity and immune system dysregulation in schizophrenia: IgGs from sera of patients hydrolyze myelin basic protein. J. Mol. Recognit. 32:e2759. https://doi.org/10.1002/jmr.2759.

Paul, S., D. J. Volle, C. M. Beach, D. R. Johnson, M. J. Powell, and R. J. Massey. 1989. Catalytic hydrolysis of vasoactive intestinal peptide by human autoantibody. Science 244:1158-1162. https:// doi.org/10.1126/science.2727702.

Petri, M. 1994. Systemic lupus erythematosus and pregnancy. Rheum. Dis. Clin. North Am. 20:87-118. https://doi.org/10.1016/S0889 $-857 \mathrm{X}(21) 00227-1$

Polosukhina, D. I., T. G. Kanyshkova, B. M. Doronin, O. B. Tyshkevich, V. N. Buneva, A. N. Boiko, E. I. Gusev, O. O. Favorova, and G. A. Nevinsky. 2004. Hydrolysis of myelin basic protein by polyclonal catalytic IgGs from the sera of patients with multiple sclerosis. J. Cell. Mol. Med. 8:359-368. https://doi.org/10.1111/j .1582-4934.2004.tb00325.x.

Polosukhina, D. I., T. G. Kanyshkova, B. M. Doronin, O. B. Tyshkevich, V. N. Buneva, A. N. Boiko, E. I. Gusev, G. A. Nevinsky, and O. O. Favorova. 2006. Metal-dependent hydrolysis of myelin basic protein by IgGs from the sera of patients with multiple sclerosis. Immunol. Lett. 103:75-81. https://doi.org/10.1016/j.imlet.2005.10 .018 .

Rechtman, D. J., B. Ferry, M. L. Lee, and H. Chapel. 2002. Immunoglobulin A ( $\operatorname{Ig} \mathrm{A})$ content of human breast milk over time. Int. J. Infect. Dis. 6(S3):S58. https://doi.org/10.1016/S1201 -9712(02)90302-4.

Rodrigues, L., V. L. P. Alves, M. M. F. Sim-Simc, and F. G. Surita. 2020. Perceptions of women with systemic lupus erythematosus undergoing high-risk prenatal care: A qualitative study. Midwifery 87:102715. https://doi.org/10.1016/j.midw.2020.102715.

Roux, M. E., M. McWilliams, J. M. Phillips-Quagliata, P. Weisz-Carrington, and M. E. Lamm. 1977. Origin of IgA secreting plasma cells in the mammary gland. J. Exp. Med. 146:1311-1322. https:/ /doi.org/10.1084/jem.146.5.1311.

Savel'ev, A. N., E. V. Eneyskaya, K. A. Shabalin, M. V. Filatov, and K. Neustroev. 1999. Autoantibodies with amylolytic activity. Protein Pept. Lett. 6:179-184.

Savel'ev, A. N., T. G. Kanyshkova, A. A. Kulminskaya, V. N. Buneva, E. V. Eneyskaya, M. V. Filatov, G. A. Nevinsky, and K. N. Neustroev. 2001. Amylolytic activity of IgG and sIgA immunoglobulins from human milk. Clin. Chim. Acta 314:141-152. https://doi.org/ 10.1016/S0009-8981(01)00691-X.

Semenov, D. V., T. G. Kanyshkova, N. A. Karotaeva, M. A. Krasnorutskii, I. A. Kuznetsova, V. N. Buneva, and G. A. Nevinsky. 2004. Catalytic nucleotide-hydrolyzing antibodies in milk and serum of clinically healthy human mothers. Med. Sci. Monit. 10:BR23-BR33.

Shuster, A. M., G. V. Gololobov, O. A. Kvashuk, A. E. Bogomolova, I. V. Smirnov, and A. G. Gabibov. 1992. DNA hydrolyzing autoantibodies. Science 256:665-667. https://doi.org/10.1126/science .1585181 .

Tanaka, A., K. Lindor, A. Ansari, and M. E. Gershwin. 2000. Fetal microchimerisms in the mother: immunologic implications. Liver Transpl. 6:138-143.

Thiagarajan, P., R. Dannenbring, K. Matsuura, A. Tramontano, G. Gololobov, and S. Paul. 2000. Monoclonal antibody light chain with prothrombinase activity. Biochemistry 39:6459-6465. https:/ /doi.org/10.1021/bi992588w.

Tincani, A., C. Nalli, J. Khizroeva, V. Bitsadze, A. Lojacono, L. Andreoli, Y. Shoenfeld, and A. Makatsariya. 2019. Autoimmune diseases and pregnancy. Best Pract. Res. Clin. Endocrinol. Metab. 33:101322. https://doi.org/10.1016/j.beem.2019.101322.

Watanabe-Fukunaga, R., C. I. Brannan, N. G. Copeland, N. A. Jenkins, and S. Nagata. 1992. Lymphoproliferation disorder in mice explained by defects in Fas antigen that mediates apoptosis. Nature 356:314-317. https://doi.org/10.1038/356314a0.

Weisz-Carrington, P., M. E. Roux, M. McWilliams, J. M. PhillipsQuagliata, and M. E. Lamm. 1978. Hormonal induction of the secretory immune system in the mammary gland. Proc. Natl. Acad. Sci. USA 75:2928-2932. https://doi.org/10.1073/pnas.75.6.2928.

Zhou, Z. H., A. G. Tzioufas, and A. L. Notkins. 2007. Properties and function of polyreactive antibodies and polyreactive antigen-binding B cells. J. Autoimmun. 29:219-228. https://doi.org/10.1016/j .jaut.2007.07.015.

\section{ORCIDS}

Ivan Yu. Kompaneets @ https://orcid.org/0000-0001-5466-5372 Sergey E. Sedykh 『 https://orcid.org/0000-0003-0882-8171 Valentina N. Buneva (1) https://orcid.org/0000-0003-2556-979X Pavel S. Dmitrenok @ https://orcid.org/0000-0002-8191-6170 Georgy A. Nevinsky ํㅜ https://orcid.org/0000-0002-4988-8923 